(1)

\title{
CONFIDENTIAL
}

,
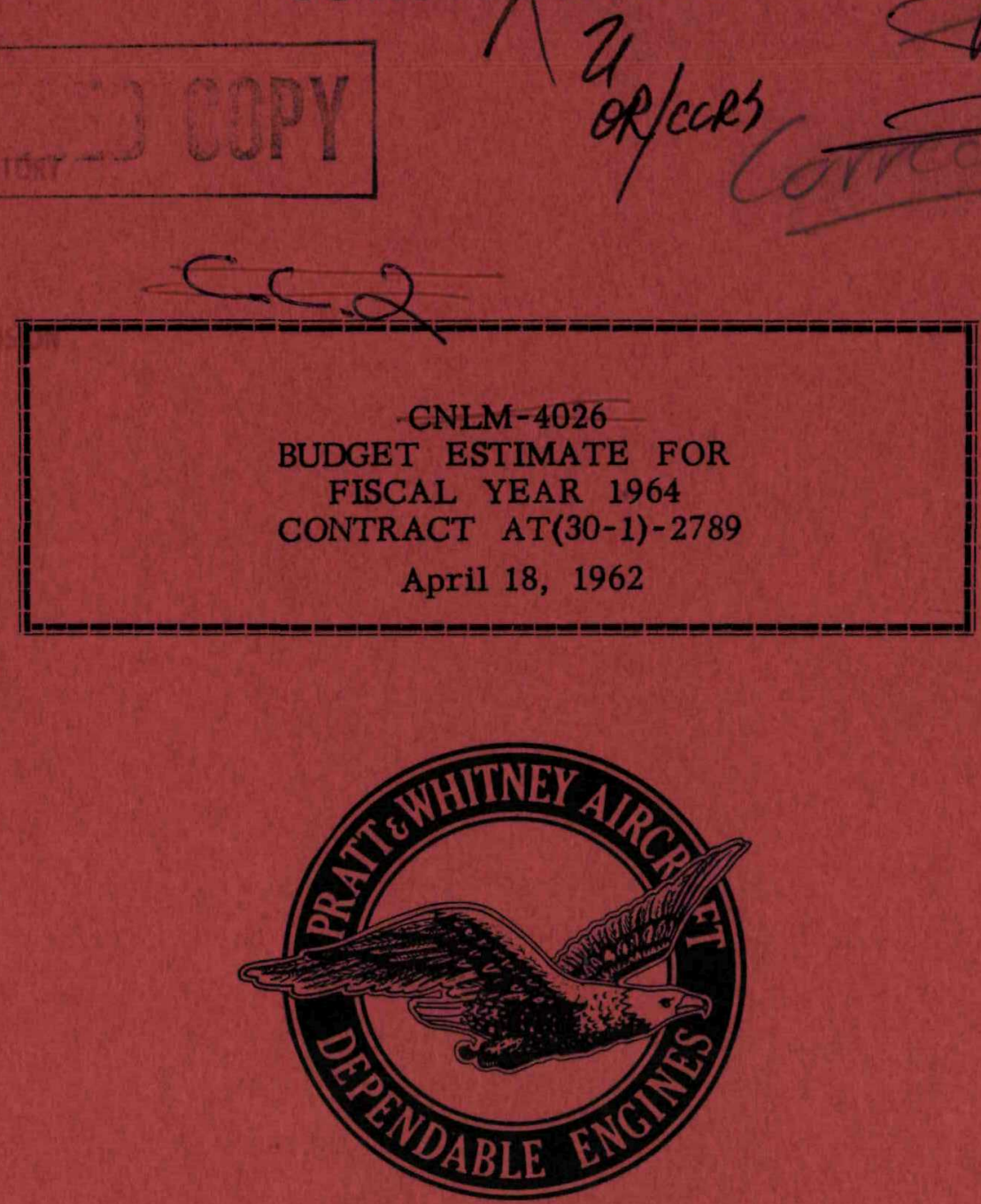

\section{RESTRICTED DATA}

This document contains restricted data as defined in the Atomic Energy Aef of 1954. Its transmittal or the disclosure of its contents in any manner to an unauthorized person is prohibited.

GPOIIP T. Exeluded from Asto 12. pietic Downgriditer And Dechinificanition

$\begin{array}{lllllllllllllllllllll}P & R & A & T & T & \& & W & H & \text { I } & T & N & E & Y & A & \text { I } & R & C & R & A & F & T\end{array}$ DIVISION OF UNITED AIRCRAFT CORPORATION CANEL

DISTRIBUTTIONO'OF THIS DOCUMENT IS UNLIMITED

\section{CONETOENTIAL}

(n)
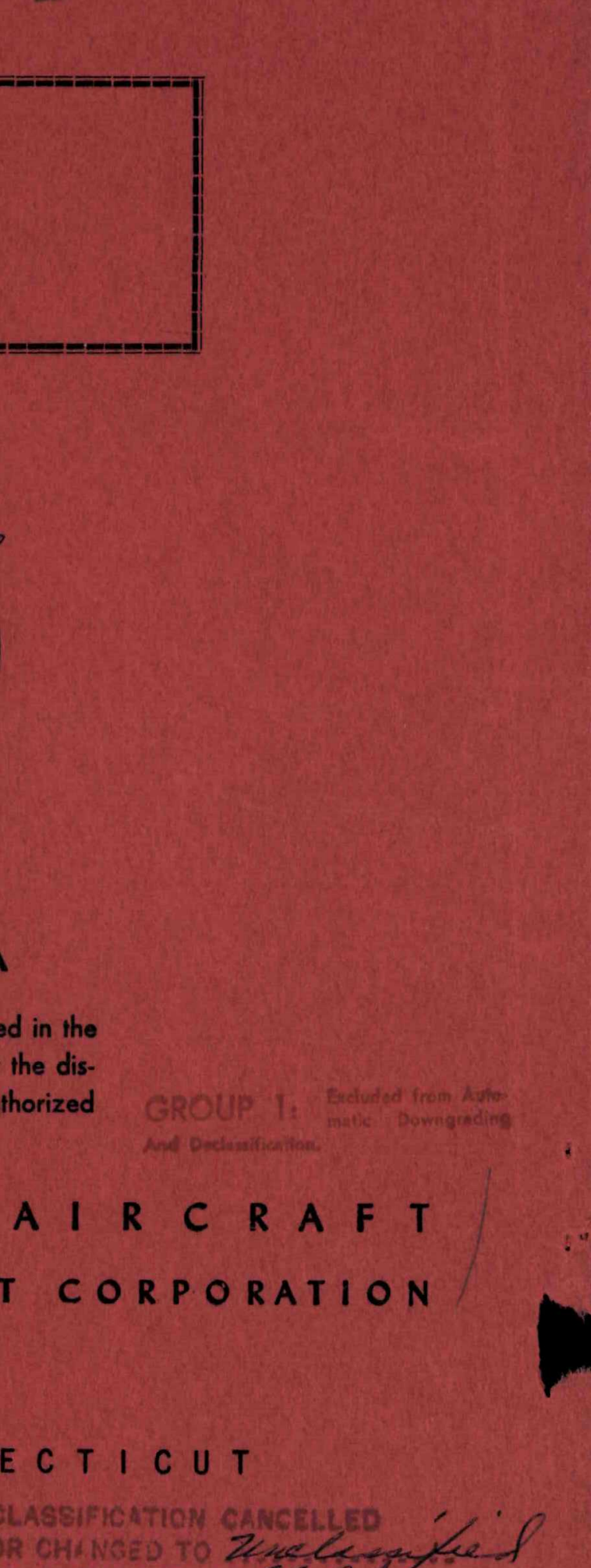

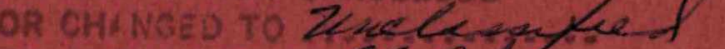
ar autranyr or cess by 


\section{DISCLAIMER}

This report was prepared as an account of work sponsored by an agency of the United States Government. Neither the United States Government nor any agency Thereof, nor any of their employees, makes any warranty, express or implied, or assumes any legal liability or responsibility for the accuracy, completeness, or usefulness of any information, apparatus, product, or process disclosed, or represents that its use would not infringe privately owned rights. Reference herein to any specific commercial product, process, or service by trade name, trademark, manufacturer, or otherwise does not necessarily constitute or imply its endorsement, recommendation, or favoring by the United States Government or any agency thereof. The views and opinions of authors expressed herein do not necessarily state or reflect those of the United States Government or any agency thereof. 


\section{DISCLAIMER}

Portions of this document may be illegible in electronic image products. Images are produced from the best available original document. 
Justification for Operating Costs

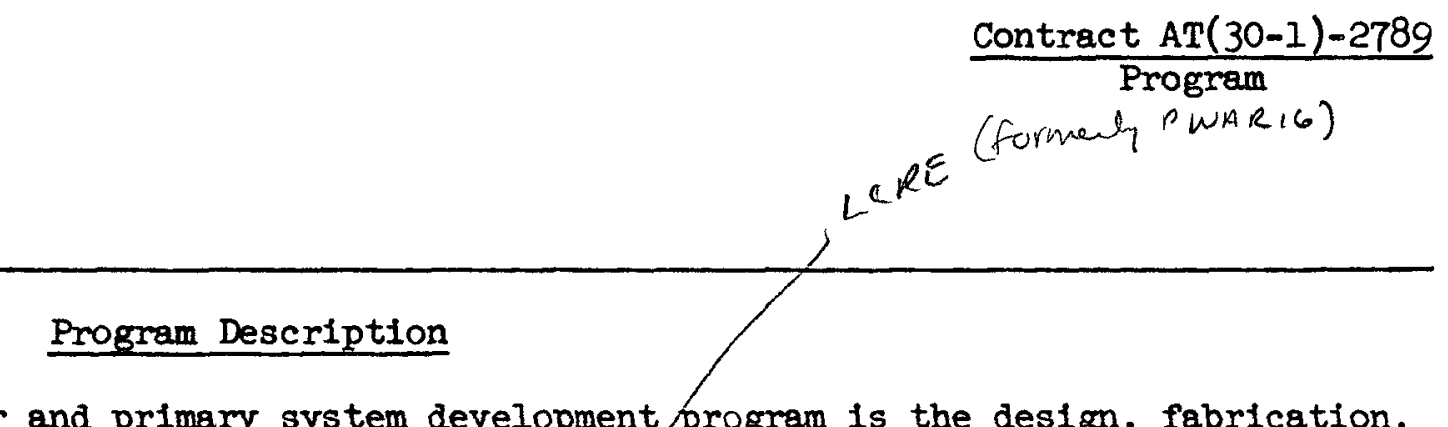

The stated objective of the SNAP-50 reactor and primary system development program is the design, fabrication, development and test operation of a series of reactors and associated equipment leading to a fuliy qualified and accepted SNAP-50 filight reactor and primary system. The present PWAR-16 $\mathrm{UO}_{2}-\mathrm{BeO}$ lithium cooled, compact, $\therefore \cdots$ : fueled reactor experiment now in progress at CANEL is the important first step in the development of the SNAP-50 reactor and primary system.

The next step in the program will be a 10,000 hour, full power test of the SNAP-50 prototype reactor and the primary system which consists of reactor, controls, lithium pumps, and lithium-heated bollers. As presently proposed, the reactor and primary system will be tested with a stationary heat rejection system probably consisting of a spray condenser, pumps, and a liquid-metal-to-air heat exchanger. Insofar as possible, components Identical to those used in the PWAR-16 experiment heat rejection system including pumps, valves, and Ilquidmetal-to-alr radiators will be used.

The third step of the program consists of a series of systems tests of the complete SNAP-50 powerplant arranged in its flight configuration; the tests wlll be conducted in a simulated space environment to achieve flight qualification.

Assuming that the beneficial occupancy date for the PWAR-16 reactor test facility is not later than December 1 , 1963 and that the additional six million dollars requested for the present PWAR-16 program in Fiscal Year 1963 will be provided, we estimate that the dates for the start of the tests defined above are as follows:

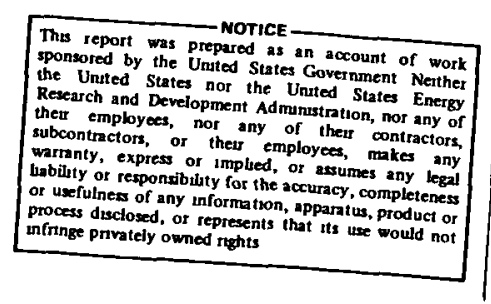

DISTRIBUTTION OF THIS DOCUMENT IS UNLIMITED

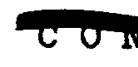

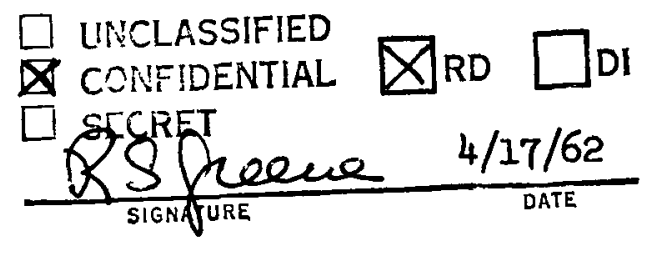

$\therefore \ldots$

:::..:

(.......

(.....

$\because \cdots$

$\because \because$

$\because \because$

$\because \because:$

$\because \ldots$

$\therefore \therefore$

$\vdots . . .$. :a...: 


\section{Type of Test}

PWAR-16 Reactor Experiment

Prototype Reactor Development

\section{Starting Date}

December 1964

July 1966

July 1967 $\therefore \ldots$

¿...::

$\ldots . .$.

$\ldots . .:$

$\ldots \ldots$

$\because \because \because$

$\because \because$

(....

$\vdots \ldots$

$\therefore \ldots$

:...: :

$\therefore \ldots$ :

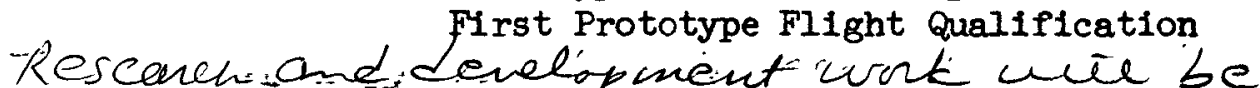

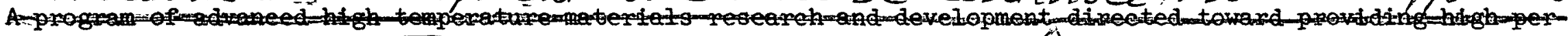

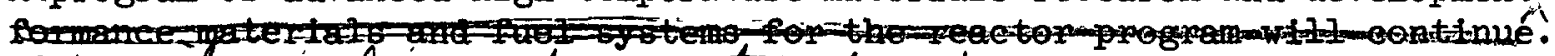
privercle JUSTIFICATION

04-50-06-01 LCRE

PWAR=I6 Reactor Program

\section{Activity .I}

Fiscal Year 1962: The research and development programs on pressure vessel, reactor internal structure and core, control drive, piping and mount system, system hydrodynamics, experimental physics, shielding, pumps, heat exchangers, valves, controls and reactor system auxiliaries were initiated.

F1scal Year 1963: The research and development programs on pressure vessels, reactor internal structure and core, control drives, piping and mount systems, system hydrodynamics, experimental physics, shielding, pumps, heat exchangers, valves, controls, and reactor system auxillaries will be continued. These programs are directed toward providing the information required in the design PWAR-16 reactor experiment and toward developing the components to be used in the heat removal systems.

F1scal Year 1964: Research and development will continue on the PWAR-16 reactor experiment, the primary and secondary liquid metal systems, and control and safety systems. Critical experiments and the materials development will continue. $\therefore \ldots$

:::...

(......

$\vdots . .$.

$\because \cdots$

$\therefore$

$\because \because$

$\because \ldots$

$\ldots \ldots$

$\therefore$

: :...:

:.....: 
Schedule 2la.

Justification for Operating Costs

New York Operations Offlce

Pratt \& Whitney Aircraft - CANEI

Contract AT(30-1)-2789

Middletown, Connecticut

\section{Activity .2}

Flscal Year 1962: Fabrication of $\mathrm{UO}_{2}-\mathrm{BeO}$ fuel elements for the core of the PWAR-16 reactor experiment was initiated.

F1scal Year 1963: Fabrication of $\mathrm{WO}_{2}-\mathrm{BeO}$ fuel elements for the core of the PWAR-16 reactor experiment will be continued.

Fiscal Year 1964: Fabrication of fuel elements for the core of the $\mathrm{UO}_{2}-\mathrm{BeO}$ fueled reactor experiment will be completed.

\section{Activity .4}

Fiscal Year 1962: Procurement of long lead 1tems for the PWAR-16 reactor experiment and fabrication of certain components was intiated.

Fiscal Year 1963: Fabrication work initiated in fiscal year 1962 on the PWAR-16 reactor experiment will be continued during this fiscal year and all other fabrication of components required for the experiment will be started.

Fiscal Year 1964: Work will be directed towards completion of fabrication and assembly of the PWAR-16 reactor. Installation of the reactor system in the Test Facility will be initiated.

\section{Activity .6}

Fiscal Year 1962: Approximately 1,490 irradiation units were used.

Fiscal Year 1963: The estimated usage of irradiation units is 1,365.

Fiscal Year 1964: The estimated usage of irradiation units is 695 . 
Schedule 2la.

Justification for Operating Costs

New York Operations Office

Contract AT(30-1)-2789

Program

Pratt \& Whitney Aircraft - CANEL

Middletown, Connecticut

\section{Activity .7}

Fiscal Year 1962: $\mathrm{UO}_{2}$-BeO fuel specimens and reactor system components were encapsulated, irradiated and examined following irradiation.

Fiscal Year 1963: $\mathrm{UO}_{2}$-BeO fuel materials and reactor system components will be prepared and encapsulated for irradiation tests. Post irradiation examination will be conducted.

Fiscal Year 1964: The preparation of fuel samples and reactor components for irradiation will be continued.

\section{Activity .9}

Fiscal Year 1962: Capital equipment acquired included transformers, D.C. rectifiers and contactors, blower, water pump, temperature control indicators and recorders, gas analyzers, vacuum equipment, amplifiers, level indicators, pressure indicators and recorders.

Fiscal Year 1963: Capital equipment to be procured in fiscal year 1963 includes gas sensors, printing digital voltmeter, transformers, rectifiers, gas purifier, temperature indicators and controls, pressure and flow indicators, gas purifiers, log count rate meters and recorders.

Fiscal Year 1964: Capital equipment to be purchased will include sub-critical nuclear instrumentation system, linear power range nuclear instrumentation system, pile oscillator nuclear instrumentation system, start-up nuclear instrument system, intermediate log nuclear instrumentation system, power log instrumentation as well as recorders, gas analysis sensors and miscellaneous instrumentation.

:....:

$:: . .: \vdots$ (2.... $\vdots . . .$. (....... $\because \because$ $\because \because$ $\therefore$ .....: $\therefore .$. :...: :.....: 
Schedule 2la.

Justification for Operating Costs

New York Operations Office

Contract $A T(30-1)-2789$

Program

Pratt \& Whitney Aircraft - CANEI

Middletown, Connecticut

$04-30-03-02$

SNAP-50 Program

\section{Activity .I}

$\therefore . .$.

$\vdots . .:::$

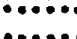

$\ldots:$ :

…...

$\because \because:$

$: \because \because$

$\because \because$

(.......

$\therefore \therefore$

$\vdots . . . . \vdots$

$\therefore \cdots$ :

Fiscal Year 1962: Research and development work was initiated in the following areas: SNAP-50 analytical systems studies, preliminary powerplant arrangement studies, parametric reactor and primary system studies at 300,500 , and $1,000 \mathrm{kw}$ (e), preliminary design of the reactor primary pump boiler shielding and auxiliary systems, in and out-of-pile uranium carbide fuel tests, reactor and the pump bearing materials liquid metal compatibility, design of the primary pump cavitation damage materials screening test rig, design of the primary pump test rigg, design of the boiling heat transfer experimental rig, preparation of critical experiments for the SNAP-50 reactor and preparation of a preliminary development plan for the SNAP-50 reactor and primary system and nuclear electric powerplant.

Fiscal Year 1963: Research and development work will be continued or initiated in the fullowing areas: A system study of the SNAP-50 powerplant will be completed, parametric studies of the SNAP-50 reactor and primary system will be completed; preliminary design of the reactor, primary pump, boiler, shie]ding and auxiliary systems will be completed; a uranium-carbide-fuel-devel-pment-program-will-be-continued-to-com-

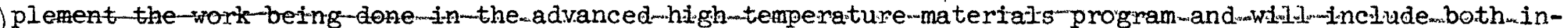

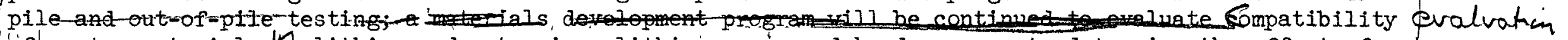
'of' system materials lo lithium and potassium, lithium vapor and hard vacuum, $x$ Iiquid metal pump/and mechanical and physical properties of materiats-of interest; testing of critical components to develop design information for the potassium boiler and for the primary pump will include tests of bearings, seals, impellers and jet pumps; critical experiments on the 10 reactor will continue; 2 development program for the SNAP-50 system will be prepared. wal be defermumal couctatin studies uil be condunter will be threstuater:

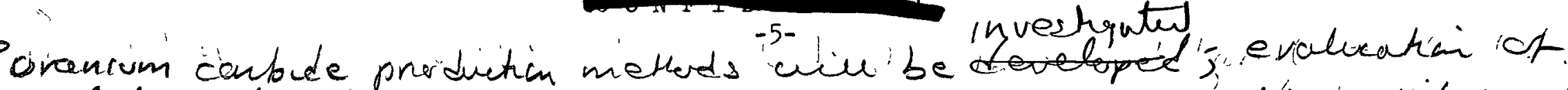

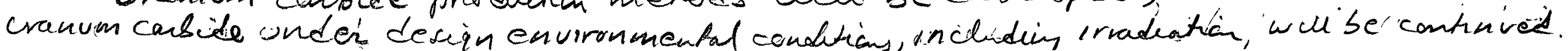


Fiscal Year 1963: (cont'd.)

$$
\text { need to uncrease ke miedenction rate, c.f }
$$

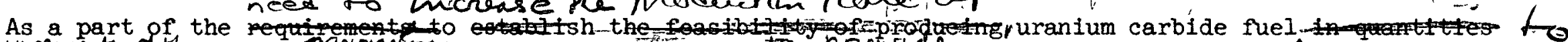

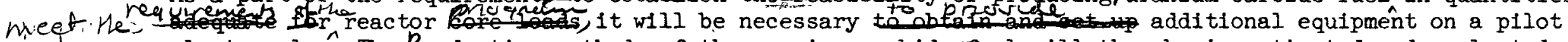
plant scale." Rroduction methods of will then be investigated and evaluated, using techniques developed in the laboratory. Afinglneering structural analysis and design methods will be extended and confirmed through a program of long term testing of reactor pressure vessel scale models. A control drive development program will be initiated in order to extend the development program of the PWAR-16 to the new conditions of the SNAP-50 program.

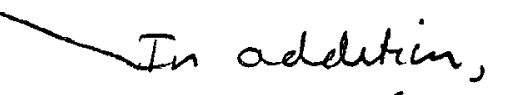

Fiscal Year 1964: The research and development effort initiated in FY 1963 will be continued and expanded to include development of jacketing and mounting systems, pressure vessel, core and internal structure, reflector, controls, valves, piping and instrumentation.

\section{Activity .6}

F1scal Year 1962: Approximately 75 irradiation units were used.

Fiscal Year 1963: Approximately 2000 irradiation units will be used on the SNAP-50 program.

Fiscal Year 1964: It is estimated that 4000 irradiation units will be used.

\section{Activity .7}

Fiscal Year 1962:

F1scal Year 1963: Irradiation.

Prepared and initiated'irrodiatiai testing y five puel caxenbe. sample-specimens-of UC fuel-were-prepared and-encapsulated-and-imaditated..

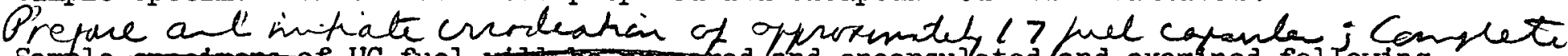
semple-spectmens of us t be prepare a

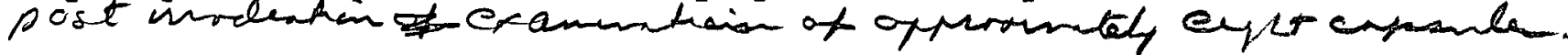

F1scal Year 1964: Fuel specimens and reactor system components will be encapsulated and examined after Irradiation. 
Justification for Operating Costs

New York Operations Office

Contract AT (30-1)-2789

Program

Pratt \& Whitney Alrcraft - CANEI

Middletown, Connecticut

\section{Activity .9}

Fiscal Year 1962: The following capital equipment will be procured: Welch pumps, vacuum gages, vacuum valves, ultra high vacuum chamber with pumps, gages, instrumentation, optical pyrometer, pyrovanes, recorders, portable gas analyzer, sacuum furnace, laboratory press, analytical balance, vacuum dry box and high frequency power supply.

$$
\text { pellet vere, }
$$

Fiscal Year 1963: Capital equipment will include: A temperature controllers, furnace, powerstats, transformers, recorders, gas analyzers, speed indicators and temperature indicators. Additional equipment will be procured for the uranium carbide fuel pilot production program including dry boxes, furnaces, hydrogen purifier, agglomerator, automatic wire and particle classifier.

Fiscal Year 1964: Capital equipment to be procured for the SNAP-50 program will include liquid metal purification systems, high temperature electric furnaces, vacuum chambers including pumps, gages, valves, etc., transformers, rectifiers, high frequency generators, dynamometers, high temperature electromagnetic pumps and miscellaneous instrumentation.

04-40-02-01

Advanced High Temperature Materials

Activity.I

$$
\text { Reseach continued an an erpat to develop }
$$

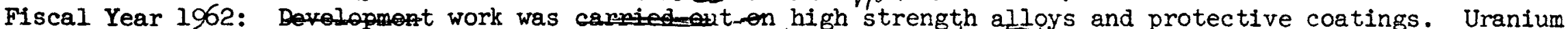

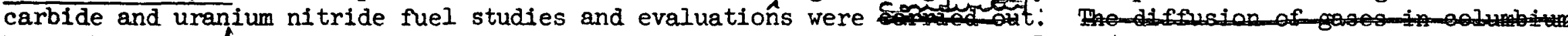

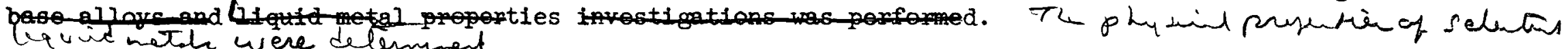

Fiscal Year 1963: Development work will continue on high strength alloys and protective coatings. Fuel studies and evaluations will be conducted. Diffusion of gases liquid meta

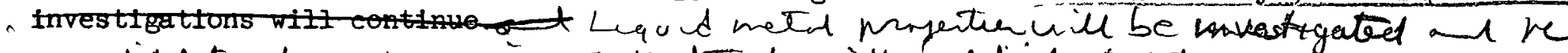

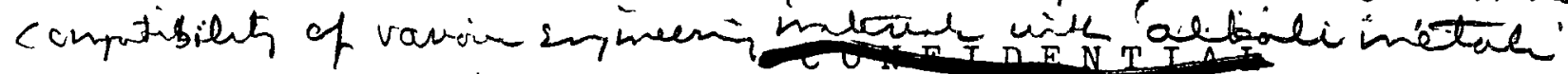

wul be evaluatull

$\therefore \ldots:$

$\therefore:$ ...... : $\therefore . .$. $\ldots$ $\because \because$

$\because \because$

$\because \cdots$

.....:

$\therefore \therefore$

$\vdots . . .$. :....: 
Schedule ala.

Justification for Operating Costs

New York Operations Office

Pratt \& Whitney Aircraft - CANEL Middletown, Connecticut
Contract $\operatorname{AT}(30-1)-2789$

Program

Fiscal Year_1964:-_Research_and_development_work_on_alloys,_coatings,_fuels,_liquid_metals,-and_diffusion-will be continued.

Activity .6

Fiscal Year 1962: Approximately 821 Irradiation units were used in the Advanced High Temperature Materials Program.

Fiscal Year 1963: It is estimated that 900 irradiation units will be required in this period.

Fiscal year 1964: It is estimated that 2000 irradiation units will be required.

Activity. 7 (included in Acuity. I foundry)

Fiscal Year 1962: Fuel materials of uranium nitride-columbium cermet and uranium carbide ceramic were prespared and encapsulated for irradiation testing. Post irradiation examination was made.

Acverneed fuel compounds

Fiscal Year 1563: prepared and encapsulated for irradiation testing. Post irradiation examination will be made.

Fiscal Year 1964: Preparation and encapsulation of fuel materials of interest and post irradiation examination will be continued.

Acturty. 9

Fiscal fen 1962 -.

$-8-$

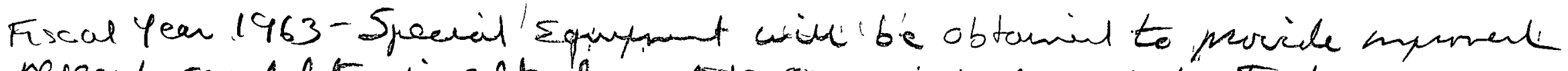

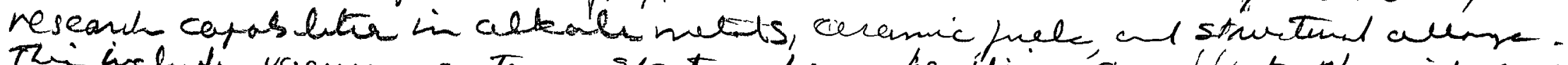

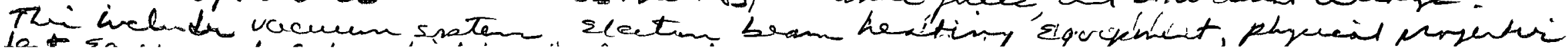


Schedule 2la.

Justification for Operating Costs

New York Operations Office

Contract AT(30-1)-2789

Program

Pratt \& Whitney Aircraft - CANEL

Middletown, Connecticut

$04=90=00=09$

\section{General Capital Equipment}

Fiscal Year 1964: These funds are required to procure General Purpose Capital Equipment items; i.e., instruments, other laboratory apparatus, and shop process equipment to further develop and insure the quality of columbium fabrication. In addition, we will require other miscellaneous capital items that cannot be specifically identified at this time.

\section{JUSTIFICATION OF CHANGES}

1. PWAR-16 Reactor Program

Fiscal Year 1963: The estimated cost of this program has increased from the $\$ 16,490,000$ originally estimated to $\$ 21,958.6$.

Additional technical information has become available since the submission of the proposed budget for fiscal year 1963. A development program objective of a full power operating lifetime of 10,000 hours was established for the PWAR-16 reactor experiment. Use of a regenerative cycle in the heat removal system to reduce component operating temperatures and extended development testing to provide a higher level of reliability on reactor system components are necessary to meet the extended operating lifetime requirement. In the period since the submission of the proposed budget, reactor design layouts have been completed and the heat removal system design concept has been established. Availability of this information permitted a more accurate estimate of development schedules and operating costs required to develop, construct and start operation of the reactor experiment.

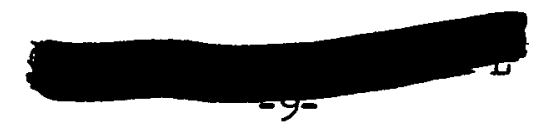


Schedule 2la.

Justification for Operating Costs

New York Operations Office

Contract $\operatorname{AT}(30-1)-2789$

Program

Pratt \& Whitney Alrcraft - CANEL

Middletown, Connecticut

\section{Fiscal Year 1963: (cont'd)}

Recent experience in development testing of components in lithium and in fabricating welded components from columbium alloys has clearly established a requirement for improved quality standards in fabricating and handling columbium alloy materials and components. These improved standards are necessary to prevent contamination of columbium alloy material and welds, primarily by oxygen. Identification of this problem and confirmation of corrective action to be taken are based on vigorous efforts in laboratory investigations and in the improvement of fabrication and material handling equipment and techniques. The recessity to accoriplish this work prior to continuing fabrication of reactor components for development testing is reflected in. the extension of development test schedules. In addition, it will be necessary to repeat certain structural and corrosion development tests in which difficulty was experienced.

Additional estimated direct labor and overhead costs are the result of a proposed increase in personnel assigned to the program of 200 over a period of four months starting in July 1962. The added capability will be in the experimental constmuction and development testing groups with a corresponding increase in the indirect labor group.

A large increase in the estimate for direct material resulted from a rigorous examination of requirements when the design of the PWAR-16 stabilized. These requirements include $\$ 2,000,000$ for columbium, $\$ 800,000$ for stainless steel and other material, $\$ 400,000$ for conversion of columbium and $\$ 3,900,000$ for finished parts and outside fabrication.

Fiscal Year 1964: The estimated cost of the PWAR-16 program for this year is $\$ 12,812,000$. This group presents an increase of $\$ 1,750,000$ over the previous estimate of $\$ 11,062,000$ and reflects additional costs brought about by conducting the PWAR-16 experiment in the Flight Engine Test Facility at the National Reactor Testing Station, Idaho. This additional cost has been analyzed in CANEL document CNLM-3842 but represents an increase of indirect labor for the Idaho Facility, moving expenses for personnel transferred from Connecticut to Idaho, shipping expenses for reactor experiment hardware and additional travel expense between Connecticut and Idaho.

Fiscal year 1964 costs are less than those estimated for fiscal year 1963 because of the completion of fabrication of the PWAR-16 reactor experiment.

:...::

::...: ...... (... $\because \cdots$ $\because$ $\cdots$ $\ldots$ $\because \ldots$ :...: :....: PIL 
Pratt \& Whitney Aircraft - CANEI

\section{SNAP-50}

Fiscal Year 1962: Work on the SNAP-50 program was initiated at Pratt \& Whitney Aircraft - CANEL Operation in April, 1962. The estimated expenditure of $\$ 600,000$ therefore appears in the budget estimate for the first time.

Fiscal Year 1963: The estimated cost of this program for fiscal year 1963 will be $\$ 4,006,400$ and reflects the full scale initiation research and development work on the nuclear electric power system for space application. This sum includes $\$ 506,400$ transferred from the reactor program and originally allocated for work on the PWAR-18 reactor experiment.

Fiscal Year 1964: The SNAP-50 research and development effort will expand in fiscal year 64 to an estimated cost of $\$ 26,300,000$. This extremely rapid expansion of work of this program is required to meet a scheduled test of the reactor and primary system in July of 1966.

\section{Advanced High Temperature Materials Program}

There is no change in the scope of work forecast for this program in fiscal years 1963 and 1964. The minor changes indicated result from minor adjustements in rates. 
SCHEDULE $21 a$

Analysis of Operating Expenses by Program and Contractor (In Thousands)

New York Operations Office

Field office or Laboratory

\section{Activity}

PWAR-16 Reactor

$04-50-06-01$

-1 Research \& Development

-2 Fuel Fabrication

-3 Reactor Exp. Ass'y. \& Oper.

-4 Reactor Exp. Fabrication

-6 Irradiation Charges

-7 Test Reactor Exp.

-9 Related Cap. Equip.

PWAR-18 Reacto

04-50-06-0I

-1 Research \& Development

SNAP-50

04-30-03-02

-1 Research \& Development

-6 Irradiation Charges

-7 Test Reactor Exp.

-9 Related Cap. Equip.

Advanced High Temperature Materials 04-40-02-01

-1 Research \& Development

-6 Irradiation Charges

-7 Test Reactor Exp.

-9 Related Cap. Equip.
Contract No. A.T (30-1)-2789

Program

\begin{tabular}{llll}
\multicolumn{4}{c}{1963} \\
\hline & Contractor's & Field & Program \\
Cong. & Revised & Office & Division \\
Budget & Estimate & Fstimate & Estimate
\end{tabular}

1962

Budget

Estimate

$\$ 15293.0$

14039.6

$\$ 16490.0 \quad \$ 21958.6$

10860.2

719.0

$101.0 \quad 9294.3$

27.3
807.8

92.0

$\$ 150.4$

$\$ 600.0$

359.6

1.5
108.9

108.9
130.0

956.0
749.0

11.0

188.0
8.0
$\$ 4006.4$

3061.5

40.0

582.7
322.2

iz<.

$\$ 1112.0 \$ 1035.0$

944.5

18.0

72.5
United Aircraft Corporation Pratt \& Whitney Aircraft - CANEL Middletown, Connecticut

Contractor

\begin{tabular}{|c|c|c|c|c|}
\hline \multicolumn{5}{|c|}{1964} \\
\hline & & Field & Program & \\
\hline $\begin{array}{l}\text { BRC } \\
\text { Estimgte }\end{array}$ & $\begin{array}{l}\text { Contractor's } \\
\text { Request }\end{array}$ & $\begin{array}{l}\text { Office } \\
\text { Request }\end{array}$ & $\begin{array}{l}\text { Division } \\
\text { Request }\end{array}$ & BRC \\
\hline & Request & & Request & Markup \\
\hline
\end{tabular}

$\$ 12812.0$

5088.4

59.9
778.0

6187.9

13.9

165.0

:.....:

$::: . .:$

$\because \cdots . .$.

$\because \therefore \ldots$

23000.0

970.0

80.0

950.0
1000.0

$\$ 1097.0$

1004.0

18.0

75.0 
SCHEDULE $21 a$

Analysis of Operating Expenses by Program and Contractor (cont'd.)

(In Thousands)

$\frac{\text { New York Operations office }}{\text { Field Office or Iaboratory }}$

\section{Activity}

General Capital Equipment 04-90-01-99

Total Contract

-1 Research \& Development

-2 Fuel Fabrication

-3 Reactor Exp. Ass'y. \& Oper.

-4 Reactor Exp. Fabrication

-6 Irradiation Charges

-7 Test Reactor Exp.

-9 Related Cap. Equip.

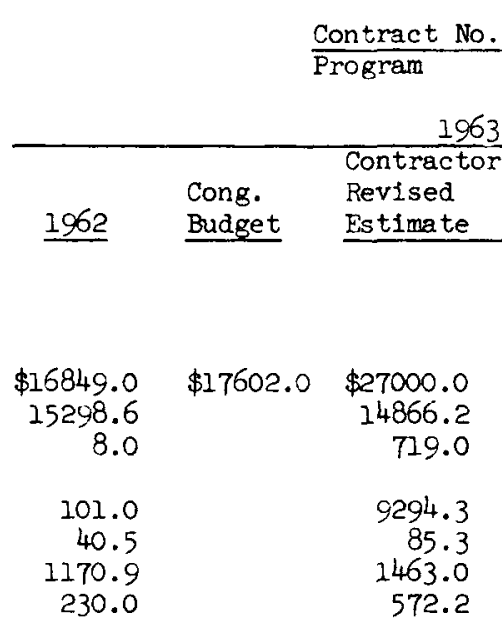

United Aircraft Corporation

Pratt \& Whitney Aircraft - CANEI Middletown, Connecticut

Contractor

\begin{tabular}{|c|c|c|c|c|}
\hline \multicolumn{5}{|c|}{1964} \\
\hline & & Field & Program & \\
\hline $\begin{array}{l}\text { BRC } \\
\text { Estimate }\end{array}$ & $\begin{array}{l}\text { Contractor's } \\
\text { Request }\end{array}$ & $\begin{array}{l}\text { Office } \\
\text { Request }\end{array}$ & $\begin{array}{l}\text { Division } \\
\text { Request }\end{array}$ & $\begin{array}{l}\text { BRC } \\
\text { Markup }\end{array}$ \\
\hline
\end{tabular}

$\$ 1000.0$

$\$ 37909.0$

27062.4

59.9

77.0

6187.9
111.9

111.9
1543.9

2165.0 an:

$\therefore: .:$

8000

(......

$\because \because \cdots$

$\because \because$

$\cdots$

……

.....:

$\therefore \therefore$

$\vdots \ldots$

:...:: 
SCHEDULE $2 \mathrm{l} \mathrm{b}$

Operating Contractor Year - End Employment by

Program and Organization for FY 1962

\begin{tabular}{|c|c|c|c|c|}
\hline Department or Division & $\begin{array}{l}\text { Reactor } \\
\text { Program } \\
\text { 04-50-06-1 }\end{array}$ & $\begin{array}{l}\text { Advanced } \\
\text { Materials } \\
\text { 04-40-02-01 }\end{array}$ & $\begin{array}{l}\text { SNAP-50 } \\
04-30-03-02\end{array}$ & Total \\
\hline $\begin{array}{l}\text { Direct Fmployment (Full Time) } \\
\text { Engineers and Scientists }\end{array}$ & 279 & 21 & 70 & 370 \\
\hline Technicians and Other Salary & 203 & 18 & 19 & 240 \\
\hline Hourly & 393 & 6 & 27 & 426 \\
\hline $\begin{array}{l}\text { Sub-Total Direct } \\
\text { (Full Time) }\end{array}$ & 875 & 45 & 116 & 1036 \\
\hline Indirect (Full Time) & $\mathrm{xxx}$ & $x x x$ & $x x x$ & 466 \\
\hline Total Full Time & 875 & 45 & 116 & 1502 \\
\hline Temporaxy and Past-time & $-0-$ & $-0-$ & $-0-$ & $-0-$ \\
\hline
\end{tabular}




\section{SCHEDULE $21 \mathrm{~b}$}

Operating Contractor Year - End Employment by Program and Organization for FY 1963

\begin{tabular}{|c|c|c|c|c|}
\hline Department or Division & $\begin{array}{l}\text { Reactor } \\
\text { Program } \\
04-50-06-01 \\
\end{array}$ & $\begin{array}{l}\text { Advanced } \\
\text { Materials } \\
\text { 04-40-02-01 }\end{array}$ & $\begin{array}{l}\text { SNAP-50 } \\
04-30-03-02\end{array}$ & Total \\
\hline $\begin{array}{l}\text { Direct Fmployment (Full Time) } \\
\text { Engineers and Scientists }\end{array}$ & 250 & 21 & 144 & 415 \\
\hline Technicians and Other Salary & 205 & 18 & 70 & 293 \\
\hline Hourly & 500 & 6 & 94 & 600 \\
\hline $\begin{array}{l}\text { Sub-total Direct } \\
\text { (Full Time) }\end{array}$ & 955 & 45 & 308 & 1308 \\
\hline Indirect (Full Time) & $\mathrm{xxx}$ & $\mathrm{x} \times \mathrm{x}$ & $\mathrm{xxx}$ & 589 \\
\hline Total Full Time & 955 & 45 & 308 & 1897 \\
\hline Temporary and Part-Time & $-0-$ & $-0-$ & $-0-$ & $-0-$ \\
\hline
\end{tabular}


SCHEUDLE $21 \mathrm{~b}$

Operating Contractor Year - End Employment by Program and Organization for FY 1964

\begin{tabular}{|c|c|c|c|c|}
\hline Department or Division & $\begin{array}{l}\text { Reactor } \\
\text { Program } \\
04-50-06-01\end{array}$ & $\begin{array}{l}\text { Advanced } \\
\text { Materials } \\
04-40-02-01\end{array}$ & $\begin{array}{l}\text { SNAP-50 } \\
04-30-03-02\end{array}$ & Total \\
\hline $\begin{array}{l}\text { Direct Employment (Full Time) } \\
\text { Engineers and Scientists }\end{array}$ & 165 & (21) & 399 & 585 \\
\hline Technicians and Other Salary & 125 & $(18)^{3}$ & 348 & 491 \\
\hline Hourly & 210 & $6-4 j$ & 424 & 640 \\
\hline $\begin{array}{l}\text { Sub-Total Direct } \\
\text { (Full Time) }\end{array}$ & 500 & 45 & 1171 & 1716 \\
\hline Indirect (Full Time) & $\mathrm{XXX}$ & $\mathrm{XxX}$ & $x x x$ & 872 \\
\hline Total Full Time & 500 & 45 & 1171 & 2588 \\
\hline Temporary and Part-Thme & $-0-$ & $-0-$ & $-0-$ & $-0-$ \\
\hline
\end{tabular}


Schedule 22

New York

Operations Office

Fleld office

1. Balance at End of Year (Gross Total)

a. Current use (total)
(1) For issue
(2) Process spares
(3) Other

b. Standby

c. Excess

d. Less: Allowances for loss

(1) Current - use for issue

(2) Current - use process spares

(3) Standby

(4) Excess

e. Net Inventory

2. Net Change during year

3. Issues during year (from items in la (1)

4. Ratio of current use issues

to ending inventory (3/1a (1) )

\section{FY1961}

$\$ 9,661,135$.

384,040

$\frac{3,108,445}{2,753,871}$

$35 \overline{4,574 . ~}$

\section{$6,552,690$.}

Stores Inventory

P\&W Aircraft Division

CANEI

Contractor

FY1962

Fry] 963

FY1964

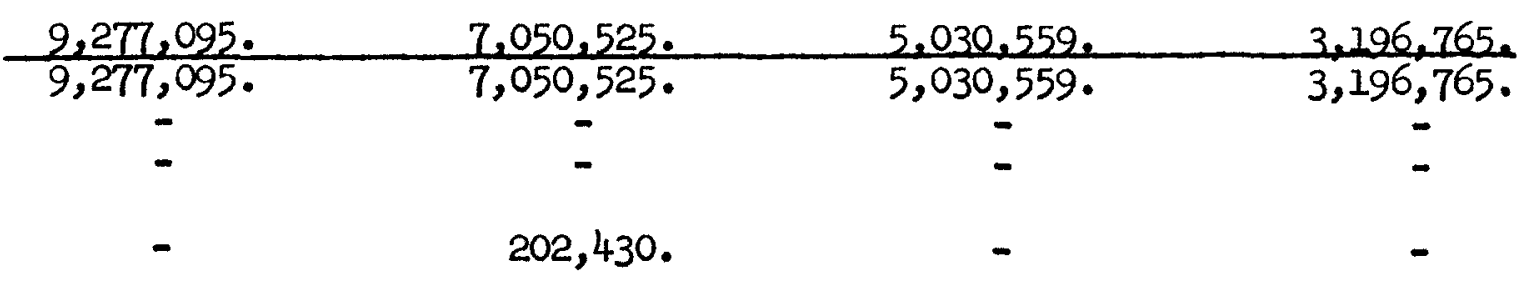

892,844 .

200,000 .

300,000 .

$3,278,827$.

$2,326,712$.

$2,462,252$.

$2,126,712$.

$\frac{2,276,712}{1,976,712}$

816,575 .

$-$

200,000 .

$-$

$4,866,972$.

$2,903,847$.

300,000 .

(1,20,053:..:

….:

\begin{tabular}{|c|c|c|c|}
\hline- & $(1,685,718)$. & $(1,963,125)$. & $(1,683,794: 0)$ \\
\hline - & $2,226,570$ & $2,019,966$ & $1,833,794^{\circ}:$ \\
\hline - & $31.6 \%$ & $40.2 \%$ & \\
\hline
\end{tabular}




\section{SCHEDULE 24}

Justification for Special Reactor Materials Inventory Transactions

New York Operations Office

Pratt \& Whitney Aircraft - CANEL

Middletown, Connecticut

Field office or Laboratory

\section{Justification for Special Reactor Materials Inventory Transactions}

1. Zirconium Ingot: 3793 Ibs. of this material will be declared excess in FY 1963 reducing the balance to zero.

2. Zirconium Fabricated Shapes: A number of parts valued at $\$ 141,718$ has been declared excess in FY 1962 reducing the balance to $\$ 2441$. This balance is carried for unspecified applications in the future.

3. Zirconium Scrap: The $\$ 141,718$ worth of fabricated parts w1ll be disposed of as scrap material in FY 1963 .

4. Zirconium Sponge: There will be a net reduction in the inventory of this material from $301 \mathrm{bs}$ in FY 1962 to an estimated 15 lbs (\$112) in FY 1964. It will be used in the alloy development program and as a gettering material.

5. Hafnium Sponge: The beginning inventory of $\$ 176 .(14.9$ lbs) will be decreased by withdrawals for alloy development. The estimated balance at the end of FY 1964 is 8.9 Ibs (\$104.) 
6. Hafnium Crystal Bar: This material will be used without depletion or scrap loss in the cold critical reactor experimental program.

7. Yttrium: There will be a net reduction in the inventory of this material from $31.416 s$ ( $\$ 4543$. ) in FY 1962 to 16.4 Ibs (\$2373) in FY 1964. It will be used in the alloy development program and as a gettering agent in hot liquid metal.

8. Boron 10: This material is used in the cold critical reactor experiment and therefore there is no depletion tinrough scrap.

i....:

i..::

.....

$\ldots . .:$ : $\cdots$ $\because \because:$ $\because \because$ $\because \cdots \cdot$ $\vdots \ldots$ $\therefore$ $\vdots . . . . \vdots$ $\because \cdots:$

9. Beryllium Metal: The usage of beryllium shown in the period will be fabricated into parts for the PWAR-16 reactor reflector assembly. The balance is held for undesignated use.

10. Beryllium Oxide Fabricated Shapes: This inventory is reduced from $\$ 664,226$ to $\$ 13,643$. $\$ 650,524$ was declared excess in FY 1962. These parts were fabricated for the PWAR-1IC program and have no present use.

11. Beryllium Oxide Scrap: $\$ 650,524$ worth of beryllium oxide fabricated shapes will be scrapped in FY 1963. 
New York Operations Office

Pratt \& Whitney Aircraft-CANEI

Middletown. Connecticut

Field Office or Laboratory

Zirconium Ingot Commodity

\begin{tabular}{|c|c|c|c|c|c|c|c|c|c|}
\hline \multirow[b]{3}{*}{ Transaction } & \multirow{2}{*}{\multicolumn{3}{|c|}{ FY 1962}} & & & & & & \\
\hline & & & & \multicolumn{3}{|c|}{ FY 1963} & \multicolumn{3}{|c|}{ FY 1904} \\
\hline & $\begin{array}{c}\text { Unit } \\
\text { Measure }\end{array}$ & $\begin{array}{l}\text { Unit } \\
\text { Cost }\end{array}$ & Amount & $\begin{array}{l}\text { Unit } \\
\text { Measure }\end{array}$ & $\begin{array}{l}\text { Unt } \\
\text { Cost }\end{array}$ & Amount & $\begin{array}{c}\text { Unit } \\
\text { Neasure }\end{array}$ & $\begin{array}{l}\text { Unit } \\
\text { Cost }\end{array}$ & Amount \\
\hline (I) & (2) & $(3)$ & $(4)$ & $(5)$ & (5) & $(7)$ & $(8)$ & (9) & $(10)$ \\
\hline
\end{tabular}

1. Summary

a. Finished Product on Hand 3793 Ibs $\$ 2.44 / 1 b \quad \$ 9271$

b. Finished Product on Lease or Loan

$\ldots . . .:$

$\vdots . .::^{2}$

...: :

$\ldots .$.

$\because \because$

$\because \because$

$\because \cdots$

$\vdots \ldots$

$\because \because$

$\vdots \ldots$

$\therefore \ldots$

c. Work in Process

d. Total Inventory

*2. Increase or Decrease (-) During

Year (to Schedule 20 )

3. Finished Products

a. Beginning Inventory July I 3793 Ibs $\$ 2.44 / 1 b \quad \$ 9271 \quad 3793$ Ibs $\$ 2.44 / 1 b \quad \$ 9271$

b. Acquisitions:
(I) Furchases

(2) Processing

(3) From other AEC Locations

Subtotal

c. Removals:

3793 Ibs $\$ 2.44 / 1 \mathrm{~b} \quad \$ 9271 \quad 3793$ Ibs $\quad \$ 2.44 / 1 \mathrm{~b} \quad \$ 9271$

\author{
3793 Ibs $\$ 2.44 / 1 b$ \$9271 (3793 Ibs) $\$ 2.44 / 1 b$ (\$9271)
}

(1) Issues

(2) Disposals

(3) To other AEC Locations Subtotal

3793 lbs $\$ 2.44 / 1 b \quad \$ 927$

d. Adjustments

e. Balance, June 30

3793 Ibs $\$ 2.44 / 1 b \quad \$ 9271$

3793 lbs $\$ 2.44 / 1 \mathrm{~b} \quad \$ 927 \mathrm{I}$

:...:

$:: . . . \vdots$

.

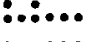

$\because \because:$

$\because \because$ .... (n...: $\because$ :...: $\because \ldots .:$ 
New York Operations Office

Pratt \& Whitney Aircraft-CANEL

Middletown. Connecticut

Zirconium Fabricated Shapes

Field Office or Laboratory Commodity

\begin{tabular}{|c|c|c|c|c|c|c|c|c|c|}
\hline \multirow[b]{2}{*}{ Transaction } & \multicolumn{3}{|c|}{ FY 1962} & \multicolumn{3}{|c|}{ FY 1963} & \multicolumn{3}{|c|}{ FY 1954} \\
\hline & $\begin{array}{l}\text { Unit } \\
\text { Measure }\end{array}$ & $\begin{array}{l}\text { Unit } \\
\text { Cost }\end{array}$ & Amount & $\begin{array}{l}\text { Unit } \\
\text { Measure }\end{array}$ & $\begin{array}{l}\text { Untt } \\
\text { Cost }\end{array}$ & Amount & $\begin{array}{c}\text { Unit } \\
\text { Neasure }\end{array}$ & $\begin{array}{l}\text { Unit } \\
\text { Cost }\end{array}$ & Amount \\
\hline (I) & (2) & (3) & (4) & (5) & (5) & $(7)$ & (8) & (9) & $(10)$ \\
\hline
\end{tabular}

1. Summary
a. Finished Product on Hand
417 pes
Var $\$ 2,441$
417 pes $\operatorname{Var} \$ 2,441$
417 pes
$\operatorname{Var} \$ 2,441$
b. Finished Product on Lease or Loan
c. Work in Process

a. Total Inventory

*2. Increase or Decrease (-) During $(59,966$ pcs) Var $(\$ 141,718)$ Iear (to Schedule 20$)^{*}$

3. Finished Products

a. Eeginning Inventory July 160,383 pes $\operatorname{Var} \$ 144,159417$ pes $\operatorname{Var} \quad \$ 2,441 \quad 417$ pes $\quad$ Var $\$ 2,441$

b. Acquistions:
(I) Purchases

(2) Processing

(3) From other AEC Locations

c. Removals:

\begin{abstract}
Subtotal
\end{abstract}
(1) Issues / Declared

(3) To other AEC Locations Subtotal

d. Adjustments

e. Balance, June 30

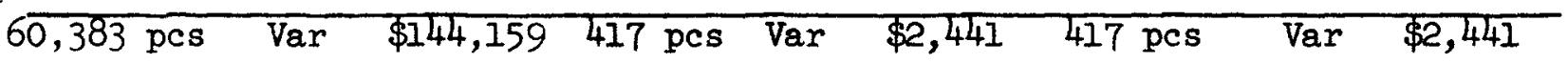

59,966 pes $\operatorname{Var} \$ 141,718$

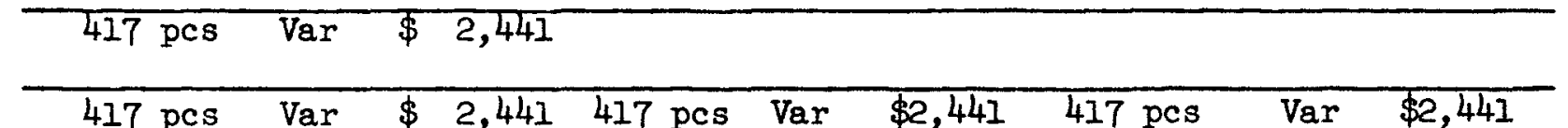

$\therefore: . .:$

$\vdots: . .$.

......

$\ldots$

$\because "$

$\because \because$

$\therefore$

...... :

$\because .$.

:....:

:......: 
New York Operations Office

Pratt \& Whitney Aircraft-CANET

Middletown. Connecticut

Zirconium Scrap

Field Office or Laboratory

Commodity

\begin{tabular}{|c|c|c|c|c|c|c|c|c|c|}
\hline \multirow[b]{2}{*}{ Transaction } & \multicolumn{3}{|c|}{ FY 1962} & \multicolumn{3}{|c|}{ FY 1963} & \multicolumn{3}{|c|}{ FY 19,04} \\
\hline & $\begin{array}{l}\text { Unit } \\
\text { Measure }\end{array}$ & $\begin{array}{l}\text { Unit } \\
\text { Cost }\end{array}$ & Amount & $\begin{array}{l}\text { Unit } \\
\text { Measure }\end{array}$ & $\begin{array}{l}\text { Untt } \\
\text { Cost }\end{array}$ & Amount & $\begin{array}{l}\text { Unit } \\
\text { Neasure }\end{array}$ & $\begin{array}{l}\text { Unit } \\
\text { Cost }\end{array}$ & Amount \\
\hline (I) & (2) & $(3)$ & (4) & (5) & (5) & $(7)$ & $(8)$ & (9) & $(10)$ \\
\hline
\end{tabular}

1. Summary

a. Finished Product on Hand 59,966 pes Var $\$ 141,718$

b. Finished Product on Lease or

$$
\text { Loan }
$$

c. Work in Process

d. Total Inventory

$\ldots:$

*2. Increase or Decrease (-) During 59,966 pcs $\operatorname{Var} \$ 141,718$ (59,966 pcs) Var $(\$ 141,718)$

iear (to Schedul

a. Beginning Inventory July 1

b. Acquisitions:

59,966 pcs Var $\$ 141,718$

(I) Purchases

(Declared

(2) Processing Excess) 59,966 pcs Var $\$ 141,718$

c. Removals:

$$
\text { Subtotal }
$$

59,966 pes Var $\$ 141,718$

$\$ 141,718$

(1) Issues

(2) Disposals

(3) To other AEC Iocations

$\$ 141,718$

d. Adjustments

Subtotal

$\$ 141,718$

e. Balance, Jinse 30

59,966 pes $\operatorname{Var} \$ 141,718$

$\therefore \ldots:$ :

$:: . . .:$

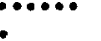

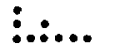

$\because$

$\because$

$\because \ldots$

(.....

$\therefore \therefore$

¿....

:....: 
SCHEDULE 24

Analysis of Special Reactor Materials Inventory Transactions

New York Operations Office

Pratt \& Whitney Aircraft-CANEI

Middletown. Connecticut

Zirconlum Sponge

Field Office or Laboratory

Commodity

\begin{tabular}{|c|c|c|c|c|c|c|c|c|c|}
\hline \multirow[b]{4}{*}{ Transaction } & \multirow{2}{*}{\multicolumn{3}{|c|}{ FY 1962}} & \multirow{2}{*}{\multicolumn{3}{|c|}{ FY 1963}} & \multirow{2}{*}{\multicolumn{3}{|c|}{ FY 19,04}} \\
\hline & & & & & & & & & \\
\hline & Unit & Unit & & Unit & Undt & & Unit & Unit & \\
\hline & Measure & Cost & Amount & Measure & $\cos t$ & Amount & Neasure & $\cos t$ & Amount \\
\hline (I) & (2) & (3) & (4) & (5) & (5) & $(7)$ & $(3)$ & (9) & (10) \\
\hline
\end{tabular}

1. Summary

$\begin{array}{llllllllll}\text { a. FInished Product on Hand } 25 \text { Ibs } \$ 7.50 / 1 b & \$ 187 & 20 \text { Ibs } & \$ 7.50 / 1 b & \$ 150 & 15 & 1 b s & \$ 7.50 / 1 b & \$ 112\end{array}$

b. Finished Product on Lease or

Loan

c. Work in Process

d. Total Inventory

*2. Increase or Decrease (-) During

Year (to Schedule 20)*

3. Finished Products

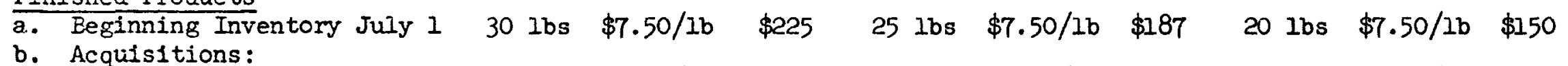
(I) Purchases
$30 \mathrm{lbs} \$ 6.75 / 1 \mathrm{~b} \quad \$ 202$
$35 \mathrm{Ibs} \$ 6.75 / \mathrm{Ib} \quad \$ 236$
$30 \mathrm{Ibs}$
$\$ 6.75 / 1 \mathrm{~b} \quad \$ 202$

(2) Processing

(3) From other AEC Iocations Subtotal

c. Removels:

(I) Issues

(2) Disposals

(3) To other AEC Locations

d. Adjustments

subtotal

\begin{tabular}{|c|c|c|c|c|c|}
\hline $60 \mathrm{Ibs}$ & $\$ 427$ & $601 \mathrm{bs}$ & $\$ 423$ & 50 lbs & $\$ 352$ \\
\hline $351 \mathrm{bs}$ & $\$ 240$ & $401 \mathrm{bs}$ & $\$ 273$ & $351 \mathrm{bs}$ & $\$ 240$ \\
\hline 35 Ibs & $\$ 240$ & 40 Ibs & $\$ 273$ & 35 Ibs & $\$ 240$ \\
\hline
\end{tabular}

e. Balance, Jine 30 
New York Operations Office

Pratt \& Whitney Aircraft-CANEL

Middletown. Connecticut

Hafnium Sponge

Field Office or Laboratory Commodity

\begin{tabular}{|c|c|c|c|c|c|c|c|c|c|}
\hline \multirow[b]{3}{*}{ Transaction } & \multicolumn{3}{|c|}{ FY 1962} & \multicolumn{3}{|c|}{ FY 1963} & \multicolumn{3}{|c|}{ FY 1904} \\
\hline & Unit & Unit & & Unit & Unit & & Unit & Unit & \\
\hline & $\frac{\text { Measure }}{(2)}$ & $\frac{\operatorname{Cos} t}{(3)}$ & $\frac{\text { Amount }}{(4)}$ & $\frac{\text { Measure }}{(5)}$ & $\frac{\cos t}{(5)}$ & $\frac{\text { Amount }}{(?)}$ & $\frac{\text { Neasure }}{(8)}$ & $\frac{\operatorname{Cos} t}{(g)}$ & $\frac{\text { Amount }}{(10)}$ \\
\hline
\end{tabular}

1. Summary

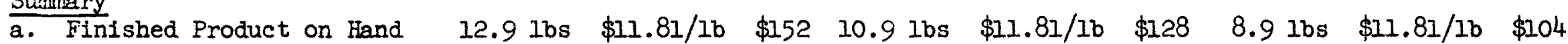

b. Finished Product on Lease or Ioan

c. Work in Process

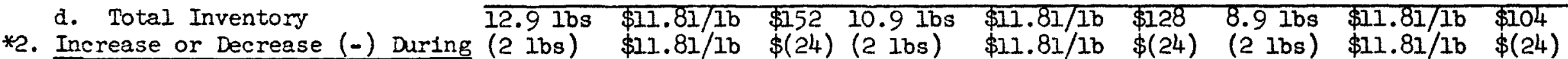
Year (to Schedule 20$)^{*}$

3. Finished Products

a. Beginning Inventory Juiy $1 \quad 14.9$ Ibs $\$ 11.81 / 1 b \quad \$ 176 \quad 12.9$ Ibs $\$ 11.81 / 1 b \quad \$ 152 \quad 10.91 b s \quad \$ 11.81 / 1 b \quad \$ 128$

b. Acquisitions :

$\begin{array}{lllllllllll}\text { (1) Purchases } & 3 \mathrm{lbs} & \$ 22.65 / 1 \mathrm{~b} & \$ 68 & 6 \mathrm{lbs} & \$ 22.65 / 1 \mathrm{~b} & \$ 136 & 1 \mathrm{lb} & \$ 22.65 / 1 \mathrm{~b} & \$ 23\end{array}$

(2) Processing

(3) From other AEC Locations Subtotal

c. Removals:

(1) Issues

(2) Disposals

(3) To other AEC Locations

d. Adjustment: Subtotal

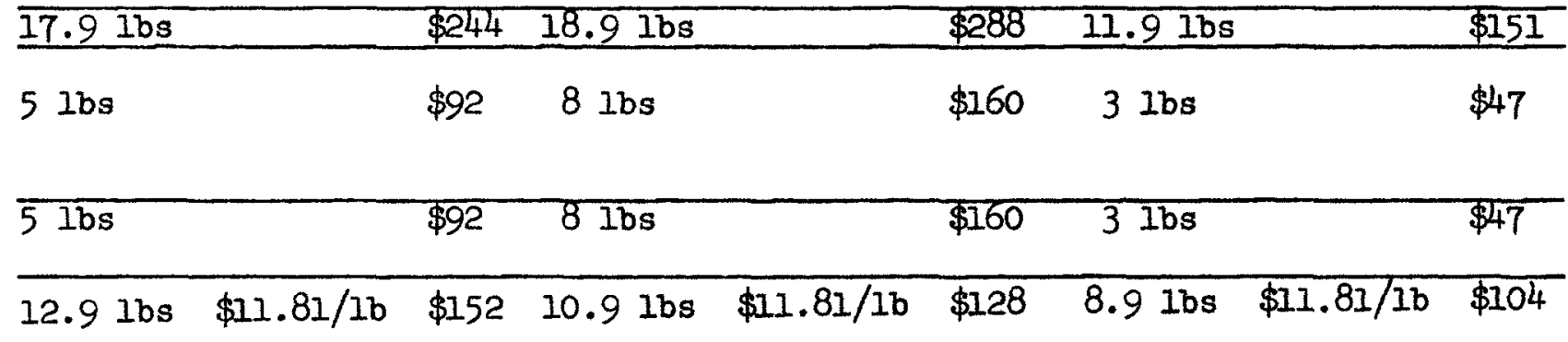

e. Balance, June 30 
New York Operations Office

Pratt \& Whitney Alrcraft-CANEI

Middletown. Connecticut

Hafnium Crystal Bar Commodity

Field Office or Laboratory

Transaction (1.)

1. Summary

a. Finished Product on Hand

11 lbs $\$ 46.45 / 1 b \quad \$ 511$

11 Ibs $\$ 46.45 / 1 b$

$\$ 511$

11 Ibs

$\$ 46.45 / 1 b \quad \$ 511$

b. Finished Product on Lease or Ioan

c. Work in Process

d. Total Inventory

*2. Increase or Decrease (-) During

Year (to Schedule 20)

3. Finished Products

a. Beginning Inventory July 1

b. Acquisitions:
(1) Purchases
11 Ibs $\$ 46.45 / 1 b \quad \$ 511$

(2) Processing

(3) From other AEC Locations

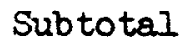
Subtotal

c. Removals:

(1) Issues

(2) Disposals

(3) To other AEC Locations Subtotal

d. Adjustments

e. Balance, June 30
II lbs $\$ 46.45 / 1 \mathrm{~b} \quad \$ 51 \mathrm{I}$ Il Ibs $\$ 46.45 / 1 \mathrm{~b} \quad \$ 511$ II lbs $\$ 46.45 / 1 \mathrm{~b} \quad \$ 511$ 11 lbs $\$ 46.45 / 1 b \quad \$ 511$

11 lbs $\$ 46.45 / 1 b \quad \$ 511 \quad 11$ lbs $\$ 46.45 / 1 b \quad \$ 511$

\begin{tabular}{llllllllll}
\hline $11 \mathrm{bs}$ & $\$ 46.45 / 1 \mathrm{~b}$ & $\$ 51 \mathrm{l}$ & 11 lbs & $\$ 46.45 / 1 \mathrm{~b}$ & $\$ 511$ & 11 & $1 \mathrm{bs}$ & $\$ 46.45 / 1 \mathrm{~b}$ & $\$ 511$ \\
\hline
\end{tabular}

11 Ibs $\$ 46.45 / 1 b \quad \$ 51 l \quad 11$ Ibs $\$ 46.45 / 1 b \quad \$ 511$ Il Ibs $\$ 46.45 / 1 b \quad \$ 511$
:...:

:::...:

(.....

$\vdots . .$.

(......

$\because \because:$

$\because \because$

$\therefore$

(.....

$\because$

$\vdots . . . . \vdots$

:.....: 
New York Operations Office

Pratt \& Whitney Aircraft-CANEI

Middletown. Connecticut

Yttrium

Field Office or Laboratory

Commodity

\begin{tabular}{|c|c|c|c|c|c|c|c|c|c|}
\hline \multirow[b]{2}{*}{ Transaction } & \multicolumn{3}{|c|}{ FY 1962} & \multicolumn{3}{|c|}{ FY 1963} & \multicolumn{3}{|c|}{ FY 1904} \\
\hline & $\begin{array}{l}\text { Unit } \\
\text { Measure }\end{array}$ & $\begin{array}{l}\text { Unit } \\
\text { Cost }\end{array}$ & Amount & $\begin{array}{l}\text { Unit } \\
\text { Measure }\end{array}$ & $\begin{array}{l}\text { Uinit } \\
\text { Cost }\end{array}$ & Amount & $\begin{array}{l}\text { Unit } \\
\text { Neasure }\end{array}$ & $\begin{array}{l}\text { Unit } \\
\text { Cost }\end{array}$ & Amount \\
\hline (I) & (2) & (3) & (4) & $(5)$ & (5) & $(7)$ & (8) & (9) & $(10)$ \\
\hline
\end{tabular}

1. Summary

a. Finished Product on Fand 26.4 lbs $\$ 144.70 / 1 b \quad \$ 3820 \quad 21.4$ lbs $\$ 144.71 / 1 b \quad \$ 3097 \quad 16.41 b s \quad \$ 144.70 / 1 b \quad \$ 2373$

b. Finished Product on Lease or Loan

c. Work in Process

d. Total Inventory

26.4 1bs $\$ 144.70 / 1 b \quad \$ 3820 \quad 21.4$ 1bs $\$ 144.71 / 1 b \quad \$ 309716.41 b s \quad \$ 144.70 / 1 b \quad \$ 2373$

*2. Increase or Decrease (-) During (5 Ibs) $\$ 144.68 / 1 \mathrm{~b} \quad \$(723)$ (5 Ibs) $\$ 144.70 / 1 \mathrm{~b} \quad \$(723)(5$ Ibs) $\$ 144.70 / 1 \mathrm{~b} \quad \$(724)$ Year (to Schedule 20)*

3. Finished Products

a. Eeginning Inventory July 131.4 Ibs $\$ 144.68 / 1 b \quad \$ 4543 \quad 26.4$ Ibs $\$ 144.70 / 1 b \quad \$ 3820 \quad 21.4$ Ibs $\$ 144.71 / 1 b \quad \$ 3097$

b. Acquisttions: (Sponge)
(1) Purchases -Sponge
-Ingot
3 Ibs
2 Ibs
$\$ 146.50 / 1 b$
$\$ 44071 \mathrm{bs}$
$\$ 146.50 / 1 b \$ 1026$
$\$ 155.00 / 1 b \$ 155$
$2 \mathrm{Ibs}$
$\$ 146.50 /$ Ib $\$ 293$
-Oxide
0.8 Ibs
$\$ 74.96 / 1 \mathrm{~b}$
$\$ 31011 \mathrm{~b}$
$\$ 74.96 / 1 b$
$1 \mathrm{lb}$
$\$ 155.00 / 1 b \quad \$ 155$

(2) Processing

(3) From other AEC Iocations
. Removals: Subtotal
(1) Issues - Sponge
- Ingot
- Oxide
Subtotal

d. Adjustments

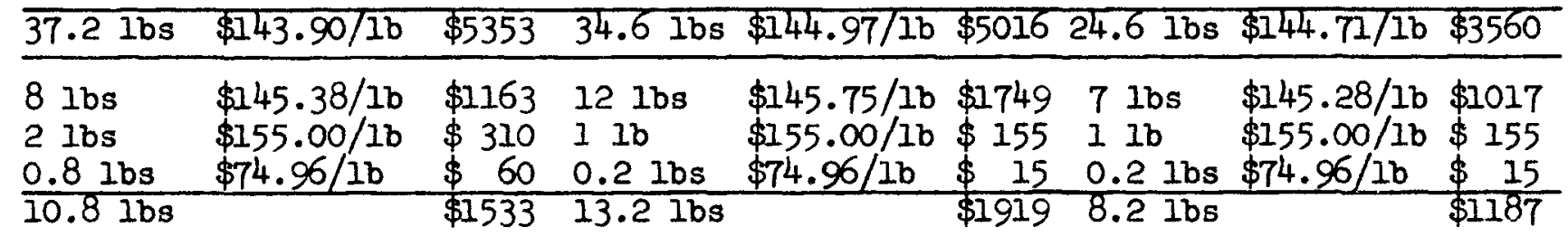

e. Balance, June 30

26.4 Ibs $\$ 144.70 / 16 \quad \$ 3820 \quad 21.4$ Ibs $\$ 144.71 / 1 \mathrm{~b} \quad \$ 3097$ 16.4 1bs $\$ 144.70 / 1 \mathrm{~b} \quad \$ 2373$

$\therefore \cdots:$

$:: . .$.

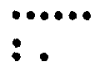

$\vdots \ldots$

$\therefore$

$\because \because$

$\because \because:$

.....:

$\therefore$

$\therefore$

$\therefore: .: \%$ 


\section{SCHEDULE 24}

Analysis of Special Reactor Materials Inventory Transactions

New York Operations Office

Pratt \& Whitney Aircraft-CANEL

Middletown. Connecticut

Field Office or Laboratory

Boron 10

Commodity

\begin{tabular}{|c|c|c|c|c|c|c|c|c|c|}
\hline \multirow[b]{2}{*}{ Transaction } & \multicolumn{3}{|c|}{ FY 1962} & \multicolumn{3}{|c|}{ FY 1963} & \multicolumn{3}{|c|}{ FY 19,04} \\
\hline & $\begin{array}{l}\text { Unit } \\
\text { Measure }\end{array}$ & $\begin{array}{l}\text { Unit } \\
\text { Cost }\end{array}$ & Amount & $\begin{array}{l}\text { Unit } \\
\text { Measure }\end{array}$ & $\begin{array}{l}\text { Unit } \\
\text { Cost }\end{array}$ & Amount & $\begin{array}{l}\text { Unit } \\
\text { Neasure }\end{array}$ & $\begin{array}{l}\text { Unit } \\
\text { Cost }\end{array}$ & Amount \\
\hline (I) & (2) & (3) & (4) & (5) & (5) & $(7)$ & (8) & (9) & (10) \\
\hline
\end{tabular}

1. Sumary

a. Finished Product on Hand 8.2 Ibs Var $\$ 2360 \quad 8.2$ Ibs $\operatorname{Var} \quad \$ 2360 \quad 8.21 \mathrm{bs} \quad$ Var $\$ 2360$

b. Finished Product on Lease or

Loan

c. Work in Process

d. Total Inventory

*2. Increase or Decrease (-) During Year (to Schedule 20)*

3. Finished Products

a. Beginning Inventory July 1

b. Acquistitions:

(1) Purchases

$6.21 \mathrm{bs}$

$\mathrm{N} / \mathrm{C} \quad-\mathrm{O}-$

$8.21 \mathrm{bs}$

$\$ 2360$

8.2 Ibs

Var $\$ 2360$

$8.21 \mathrm{bs}$

$\operatorname{Var}$

$\$ 2360$

$8.21 \mathrm{bs}$

Var $\$ 2360$

$\ldots$

$\because:$

$\because \because \cdot$

2.0 Ibs $\$ 2.60 / \mathrm{gr} \$ 2360$

or

$\$ 1180 / 1 b$

(2) Processing

(3) From other AEC Iocations

Subtotal

\section{$8.2 \mathrm{lbs}$} $\$ 2360 \quad 8.2$ Ibs

$\$ 2360$

8.2 Ibs

$\$ 2360$

c. Removals:
(1) Issues
(2) Disposals
(3) To other AEC Locations Subtotal

d. Adjustments

e. Balance, Jine 30

\begin{tabular}{llllll}
\hline $8.2 \mathrm{lbs}$ & $\$ 2360$ & $8.2 \mathrm{lbs}$ & $\$ 2360$ & $8.2 \mathrm{lbs}$ & $\$ 2360$
\end{tabular}




\section{SCHEDULE 24}

Analysis of Special Reactor Materials Inventory Transactions

New York Operations Office

Pratt \& Whitney Aircraft-CANEL

Middletown. Connecticut

Beryllium Metal

Field office or Laboratory Commodity

\begin{tabular}{|c|c|c|c|c|c|c|c|c|c|}
\hline \multirow[b]{3}{*}{ Transaction } & \multirow{2}{*}{\multicolumn{3}{|c|}{ FY 1962}} & & & & \multirow{2}{*}{\multicolumn{3}{|c|}{ FY IS, }} \\
\hline & & & & \multicolumn{3}{|c|}{ FY 1963} & & & \\
\hline & $\begin{array}{l}\text { Unit } \\
\text { Measure }\end{array}$ & $\begin{array}{l}\text { Unit } \\
\text { Cost }\end{array}$ & Amount & $\begin{array}{l}\text { Unit } \\
\text { Measure }\end{array}$ & $\begin{array}{l}\text { Untt } \\
\text { Cost }\end{array}$ & Amount & $\begin{array}{c}\text { Unit } \\
\text { Neasure }\end{array}$ & $\begin{array}{l}\text { Unit } \\
\text { Cost }\end{array}$ & Amount \\
\hline (I) & (2) & (3) & (4) & (5) & (5) & $(7)$ & $(8)$ & (9) & $(10)$ \\
\hline
\end{tabular}

1. Summary
a. Finished Product on Hand
$9.5 \mathrm{lbs} \$ 113 / \mathrm{lb} \quad \$ 1072 \quad 167.5 \mathrm{lbs}$
$\$ 16,872$
$9.5 \mathrm{Ibs} \$ 113 / 1 \mathrm{~b} \quad \$ 1,072$

b. Finished Product on Lease or Ioan

c. Work in Process

d. Total Inventory

*2. Increase or Decrease (-) During Iear (to Schedule 20)*

3. Finished Products

a. Eeginning Inventory July 1

b. Acquisitions:

(I) Furchases

9.5 Ibs $\$ 113 / 1 \mathrm{~b} \quad \$ 1072 \quad 167.5 \quad$ Ibs $158 \mathrm{Ibs}$

$\$ 100 / 1 b$

$\$ 16,872$

$\$ 15,800$

9.5 Ibs $\$ 113 / 1 \mathrm{~b} \quad \$ 1,072$

.$::$ -

$\therefore . .:$

$\because$ :

$\because:$

$\because \because \bullet$

.....

$\cdot \because$

$\cdots$

..:.:

$\ldots .$.

(2) Processing

(3) From other AEC Locations

Subtotal 19.5 lbs

$\$ 113 / 1 \mathrm{~b} \quad \$ 1072$

9.5 Ibs $\$ 113 / 1 \mathrm{~b}$

$\$ 1,072 \quad 167.5$ 1bs

$\$ 16,872$

$10 \mathrm{Ibs} \quad \$ 100 / 1 \mathrm{~b} \quad \$ 1000 \quad 358 \mathrm{Ibs} \quad \$ 100 / 1 \mathrm{~b} \quad \$ 35,800 \quad 10 \mathrm{lbs} \quad \$ 100 / 1 \mathrm{~b} \quad \$ 1,000$

c. Removals:

(1) Issues

(2) Disposais

(3) To other AEC Locations Sub total

$10 \mathrm{lb}$

$\$ 2072 \quad 367.5$ 1bs

$\$ 36,872 \quad 177.5$ Ibs

$\$ 17,872$

d. Adjustment:

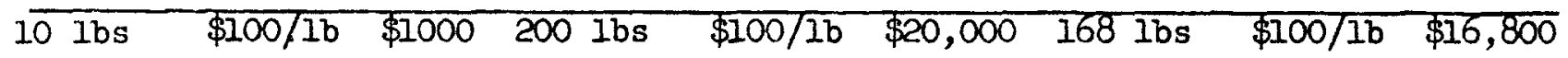

e. Balance, inse 30

$9.5 \mathrm{lbs} \$ 113 / 1 \mathrm{~b} \quad \$ 1072 \quad 167.5 \mathrm{lbs}$

$\$ 16,872 \quad 9.5$ Ibs $\$ 113 / 1 \mathrm{~b} \quad \$ 1,072$

:......:

:::..:

(…..

$\vdots . . .$.

$\because \therefore$

$\because \because$

$\because \because$

......:

$\because \because$

:....:

i......: 
New York Operations Office

Pratt \& Whitney Aircraft-CANEL

Middletown. Connecticut

Beryllium - Fabricated Shapes

Field Office or Laboratory

\section{Commodity}

\begin{tabular}{|c|c|c|c|c|c|c|c|c|}
\hline \multicolumn{3}{|c|}{$F Y 1962$} & \multicolumn{3}{|c|}{ FY 1963} & \multicolumn{3}{|c|}{ FY 19,04} \\
\hline Unit & Unit & & Unit & Unit & & Unit & Unit & \\
\hline$\frac{\text { Measure }}{(2)}$ & $\frac{\text { Cost }}{(3)}$ & $\frac{\text { Amount }}{(4)}$ & $\frac{\text { Measure }}{(5)}$ & $\frac{\cos t}{(5)}$ & $\frac{\text { Amount }}{(7)}$ & $\frac{\text { Neasure }}{(8)}$ & $\frac{\operatorname{Cos} t}{(9)}$ & $\frac{\text { Amount }}{(10)}$ \\
\hline
\end{tabular}

1. Summary

a. Finished Product on Hand 1,086 pes Var. $\$ 13,6431,086$ pes Var. $\$ 13,6431,086$ pes Var. $\$ 13,643$

b. Finished Product on Lease or Loan

c. Work in Process

d. Total Inventory

$\ldots:$ *2. Increase or Decrease (-) During
Iear (to Schedule 20)*

3. Finished Products

b. Acquis1tions :
(1) Purchases

(2) Processing

(3) From other AEC Iocations Subtotal

c. Removals:

(2) Issues - Declared

(3) To other AEC Locations Subtotal

d. Adjustment:

e. Balance, Jure 30
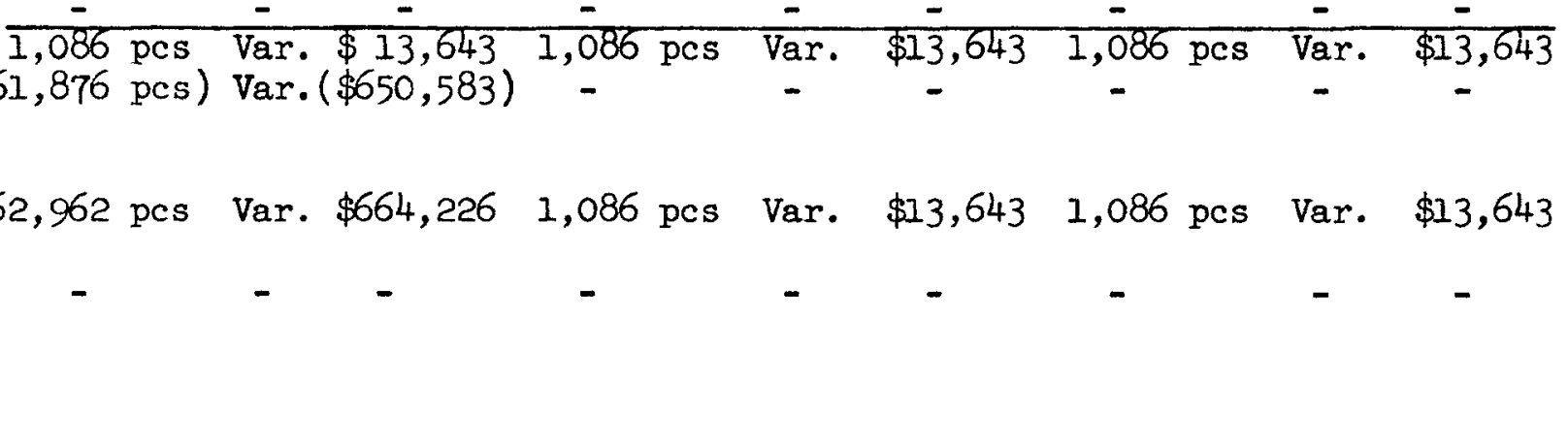

\begin{tabular}{|c|c|c|c|c|c|c|c|}
\hline $\begin{array}{r}8 \text { pes } \\
61,868 \text { pes } \\
-\end{array}$ & $\begin{array}{cr}7.40 / p c & 59 \\
\text { Var. } \$ 650,524 \\
-\quad-\end{array}$ & - & - & - & - & - & - \\
\hline $\begin{array}{c}61,876 \mathrm{pcs} \\
- \\
1,086 \mathrm{pcs}\end{array}$ & $\begin{array}{c}\text { Var. } \$ 650,583 \\
- \\
\text { Var. } \$ 13,643\end{array}$ & $1,086 \mathrm{pcs}$ & Var. & $\$ 13,643$ & 1,086 pcs & Var. & $\$ 13.643$ \\
\hline
\end{tabular}

62,962 pes $\operatorname{Var} . \$ 664,226$ 1,086 pes $\operatorname{Var} . \quad \$ 13,643$ 1,086 pes Var. $\$ 13,643$ $\therefore \cdots:$

:::..:

:

(.... $\because$

$\because \because:$

$\because \because$

(....:

$\therefore .$.

:....:

:.....: 
New York Operations Office

Pratt \& Whitney Aireraft-CANEL

Midaletown. Connecticut

Beryllium Scrap

Field Office or Laboratory

\section{Commodity}

\begin{tabular}{ccccccccc}
\hline & FY 1962 & \multicolumn{3}{c}{ FY 1963} & \multicolumn{3}{c}{ FY 1504} \\
\hline Unit & Unit & & Unit & Unit & & Unit & Unit \\
Measure & Cost & Amount & Measure & Cost & Amount & Neasure & Cost Amount \\
\hline$(2)$ & $(3)$ & $(4)$ & $(5)$ & $(5)$ & $(7)$ & (8) & (9) & (10) \\
\hline
\end{tabular}

1. Summary

a. Finished Product on Hand 61,868 pcs $\operatorname{Var} \$ 650,524$

b. FInished Product on Lease or Ioan

c. Work in Process

d. Total Inventory

*2. Increase or Decrease (-) During lear (to Schedule 20)*

3. Finished Products

a. Beginning Inventory Juiy 1

b. Acquisitions :
(1) Purchases

61,868 pcs $\operatorname{Var} \$ 650,524$

61,868 pes $\operatorname{Var} \$ 650,524(61,868$ pes $)$ Var $\$(650,524)$

\section{(1) Purches}

(2) Processing (Declared

(3) From other AEC Iocations Subtotal

61,868 pes Var $\$ 650,524$

61,868 pes $\operatorname{Var} \$ 650,524$

61,868 pes $\operatorname{Var} \$ 650,524$

c. Removals:
(1) Issues
(2) Disposals
(3) To other AEC Locations Sub total

d. Adjustments

e. Balance, June 30

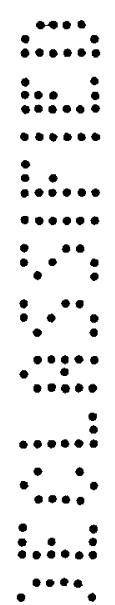

61,868 pes $\operatorname{Var} \$ 650,524$

61,868 pes Var $\$ 650,524$
61,868 pes Var $\$ 650,524$ 
New York Operations Office

Pratt \& Whitney Aircraft - CANEL

Middletown, Connecticut

\begin{tabular}{|c|c|c|c|c|c|}
\hline & (1) & $\frac{\text { FY } 1961}{(2)}$ & $\frac{\text { FY } 1962}{(3)}$ & FY 1963 & $\frac{F Y 1964}{(5)}$ \\
\hline \multirow[t]{4}{*}{1.} & $\begin{array}{l}\text { Inventory at close of Year: } \\
\text { a. Radium } \\
\text { b. Gold } \\
\text { c. Silver } \\
\text { d. Platinum } \\
\text { e. Palladium }\end{array}$ & $\begin{array}{r}99 \\
2033 \\
2018 \\
50165 \\
215 \\
\end{array}$ & $\begin{array}{r}99 \\
2015 \\
1670 \\
50165 \\
215 \\
\end{array}$ & $\begin{array}{r}99 \\
2015 \\
1670 \\
50545 \\
215 \\
\end{array}$ & $\begin{array}{r}99 \\
2015 \\
1670 \\
50925 \\
215 \\
\end{array}$ \\
\hline & $\begin{array}{l}\text { f. Barrier items: } \\
\text { Completed tubes } \\
\text { Nickel powder } \\
\text { Barrier scrap } \\
\text { Nickel ingots } \\
\text { In-process materials }\end{array}$ & $\begin{array}{l}-0- \\
-0- \\
-0- \\
-0- \\
-0-\end{array}$ & $\begin{array}{l}-0- \\
-0- \\
-0- \\
-0- \\
-0-\end{array}$ & $\begin{array}{l}-0- \\
-0- \\
-0- \\
-0- \\
-0-\end{array}$ & $\begin{array}{l}-0- \\
-0- \\
-0- \\
-0- \\
-0-\end{array}$ \\
\hline & Subtotal & $-0-$ & $-0-$ & $-0-$ & $-0-$ \\
\hline & Total Inventory & $\$ 54530$ & 54164 & 54544 & 54924 \\
\hline 2 . & Increase or decrease $(-)$ during year & $x X X$ & $(366)$ & 380 & 380 \\
\hline
\end{tabular}

\section{Schedule 25 - Justification}

No change is forecast in the inventory of Other Special Materials with the exception of an increase of $\$ 400$ in the amount of platinum in inventory at the end of FY 1964. This increase represents a slight increase in materials laboratory activity related to the SNAP-50 program. 
New York Operations Office

Pratt \& Whitney Aircraft - CANEL

Middletown, Connecticut

Field office or Laboratory
Isotopes

Commodity

Because of its classification, Schedule 26 is

included under separate cover as CNLM-4027.

$\therefore: . .:$

$\vdots . .::$

.....

....:

$\because \because$

$\because \because$

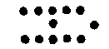

$\vdots \ldots . .$.

$\therefore .$.

$\vdots . . .:$ :

$\therefore: . .:$ :

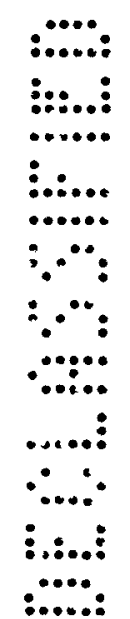

:....:

.......

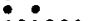

......

$\because$

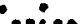
:.....: 
SCHEDULE 34

Undelivered Orders for Operations

New York Operations Office

Pratt \& Whitney Aircraft - CANEL Middletown, Connecticut

FI 1962

FY 1963
FY 1964

Undelivered Orders at End of Year

1. Major long-term Reimbursement

Contracts (Over $\$ 1.0$ million annual operating level)

e. Research \& Development

\begin{tabular}{lll}
$\$ 6,911,000$ & $\$ 9,477,000$ & $\$ 9,477, \infty 00$ \\
$\$ 6,911, \infty 00$ & $\$ 9,477,000$ & $\$ 9,477,000$ \\
\hline
\end{tabular}

7. Total Undelivered Orders 
Analysis of Undelivered Orders for Operations

As of June 30, 1963 and 1964 for Cost-Type

Contracts Funded Beyond June 30, 1963 and 1964

New York Operations Office

Pratt \& Whitney Aircraft - CANEL

Middletown, Connecticut

Field Office

\section{Justification}

The level of commitments shown in column (3) and (6) is based on the assumption that 25 percent of the material to be purchased in the following fiscal year wlll be comitted prior to the end of the previous year. The bulk of the material to be purchased for the several programs consists of special manufactured items requiring long lead times.

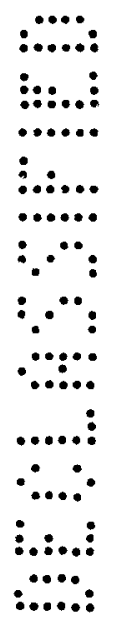


Analysis of Undelivered Orders for Operations

As of June 30, 1963 and 1964 for Cost-Type

Contracts Funded Beyond June 30, 1963 and 1964

New York Operations Office

Pratt \& Whitney Aircraft - CANEL

Middletown, Connecticut

Fleld Office

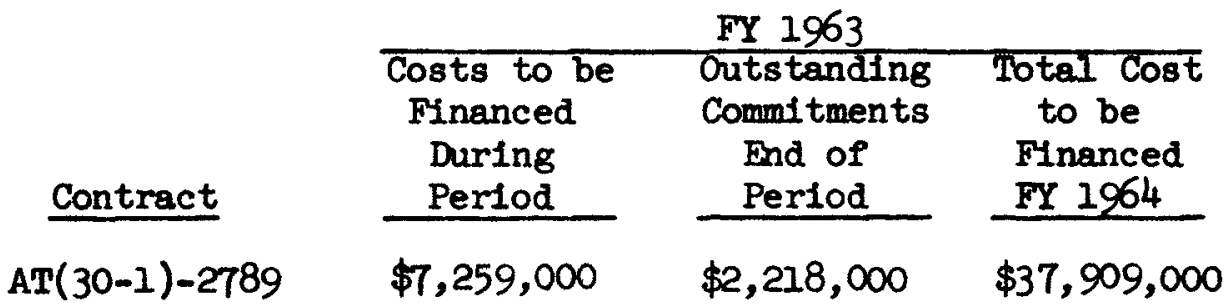

\begin{tabular}{|c|c|c|}
\hline \multicolumn{3}{|c|}{ FY 1964} \\
\hline $\begin{array}{l}\text { Costs to be } \\
\text { Financed } \\
\text { During } \\
\text { Period }\end{array}$ & $\begin{array}{l}\text { Outstanding } \\
\text { Commitments } \\
\text { End of } \\
\text { Perlod }\end{array}$ & $\begin{array}{l}\text { Iotal cost } \\
\text { to be } \\
\text { Financed } \\
\text { FY } 1965\end{array}$ \\
\hline$\$ 7,259,000$ & $\$ 2,218,000$ & $\$ 37,909,000$ \\
\hline
\end{tabular}


SCHEDULE 43

Costs Obligated and Costs Incurred for Construction Projects

New York Operations Office Field office

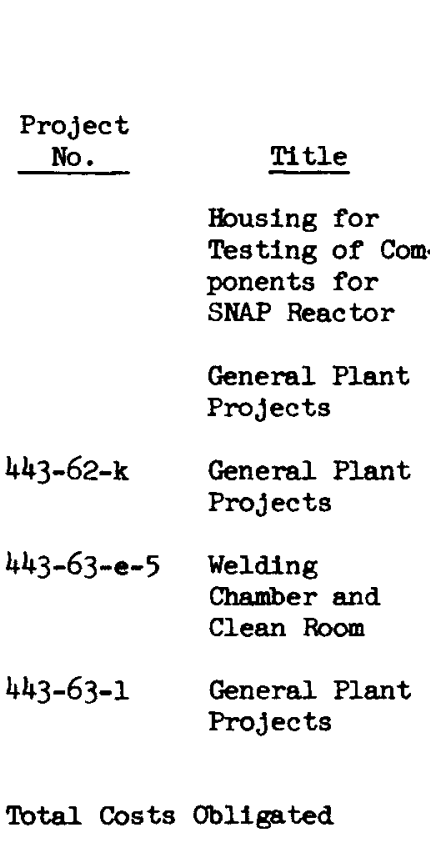

Total Obligations

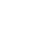

\begin{tabular}{c}
$\begin{array}{c}\text { Total } \\
\text { Est1mated } \\
\text { Cost }\end{array}$ \\
\hline
\end{tabular}

\begin{tabular}{|c|c|c|c|c|c|}
\hline \multirow[b]{2}{*}{$\begin{array}{c}\text { Non-reimb. } \\
\text { Excess } \\
\text { Ut1lized }\end{array}$} & \multicolumn{5}{|c|}{$\frac{\text { Costs Obllgated by Flscal Year }}{\text { Estimated }}$} \\
\hline & $\begin{array}{c}\text { Actual } \\
\text { to } \\
6-30-61\end{array}$ & 1962 & 1963 & 1964 & $\begin{array}{l}\text { After } \\
1964\end{array}$ \\
\hline
\end{tabular}

$\$ 190,000 \$ 2,310,000$

$\$ 542,000$

Reactor Development

Sub-Program

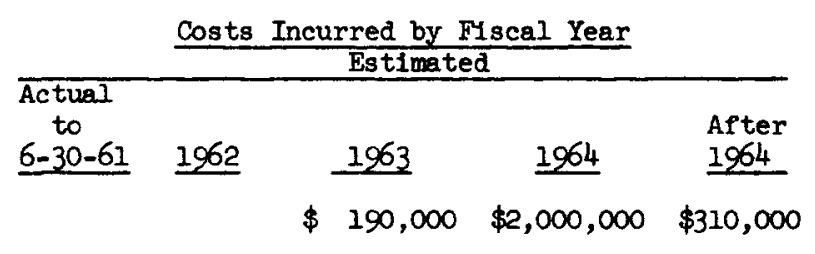

$\$ 542,000$
$\$ 106,000$

$\$ 1,400,000$

$\$ 499,000$

$\$ 499,000$

$\$ 93,000 \$ 13,000$

$\$ 15,000 \$ 1,385,000$

$\$ 5,047,000$
$\$ 399,000 \$ 100,000$

$43,000 \$ 63,000$

$\$ 15,000 \$ 1,200,000 \$ 185,000$ $\therefore: \ldots:$

$\$ 342,000 \$ 200,00 . . .$. $\therefore$

(n......

$\therefore$

$\because \because$

$\cdots$

:

$\because \cdots:$

$\therefore$

$\$ 58,000 \quad \$ 1,852,000 \quad \$ 2,627,000 \quad \$ 510,0000$.

:...: 
3. Date A-E Initiated: 3rd Quarter Calendar Year 1962

3a. Date Physical Construction Starts:

4th Quarter Calendar Year 1962

4. Date Construction Ends:

4th Quarter Calendar Year 1963

\section{Previous Cost Estimate}

None
6. Current Cost Estimate

Date April $1962 \$ 2,500,000$ $\therefore: .$.

$\vdots . .:::^{2}$

$\cdots \cdots$

$\ldots . . .:$

$\because \because$

$\because \because:$

$\because \because$

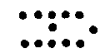

(......

$\therefore \therefore$

:...: : :

$\because \cdots$

7. Obligations and Cost Schedule:

\section{Fiscal Year \\ 1963 \\ 1964 \\ After 1964}

\section{* A and E Services}

8. Brief Physical Description of Project:

It is proposed to locate Pump Test Facilities on the east side of the Hazardous Pump-Turbine Laboratory (Bldg. 340). The addition to the present laboratory building will consist of two masonary test cells approximately $50^{\prime} \times 40^{\prime} \times 30^{\prime}$ high, very similar to cell PT-5.

The cells will house space chambers, vacuum pumps, pump drives and controls and lubrication system. Separate control rooms will be required for each cell.

Boiler test facilities will be housed in the present Heat Exchanger Laboratory modified to accept the three fluid systems and two test areas. One cell will contain a space chamber to allow a non-nuclear system test. Addition of rectifiers, modification of the heat dumps and of the present inert gas system are included.

Modifications of a minor nature will be required in the PT and Shop Laboratories. Existing CANEL services will be employed where possible.
:....:

::: :

......

¿.....

$\cdots$

$\therefore$

$\because \cdots$

$\because .:$.

.....

$\therefore \therefore$

:....:

:.....: 


\section{Justification of Need:}

Pratt \& Witney Aircraft has been selected to design and build the primary heat source system for an advanced SNAP program. This requires development of high temperature purns, dry seals, liquid metal bearings, high temperature valves, and enough boiling liquid metal work to prove the reactor and primary loop concepts. Modifications to the Pump-Turbine and Heat Exchanger Laboratories and minimal modification of the Shop Laboratory in conjunction with other facilities at CANEL will provide for fabrication, assembly, test, decontamination and evaluation of these components. As conceived, these facilities would provide the capability of testing multiple units concurrently to complete component development as required by the reactor test schedule. This requires completion of design and construction of component facilities early in Fiscal Year 1964 so that major portions of long duration test programs can be completed by the middle of Fiscal Year 1965.

10. Details of Cost Estimate:

Not Available

11. Major Contractor and Intended Type of Contract:

Architect/Engineer Contractur - Not Delected; Construction Contractor - Not Selected; Architest/Engineer Contric
CPFF; Construction Contract - Lump Sum.

12. Incorporation of Fallout Shelters in Future Federal Buildings:

$\because \cdots$

The control room or sub-grade area of the RTF will provide adequate shelter from radioactive fallout for all ${ }^{\circ}$ personnel involved in the operation of the RTF. 
New York

Construction Project Data Sheet

Operations office

Reactor Development Sub-Program

1. Title and Location of Project: General Plant Projects, CANEL, Middletown

2. Project No.

3. Date A-E Initiated: 1st Quarter CY 1962

3a. Date Physical Construction Starts: 1st Quarter CY 1962

4. Date Construction Ends: 4th Quarter CY 1963

5. Previous Cost Estimate: Date: $12 / 1 / 61$

$\$ 562,000$

6. Current Cost Estimate: Date:

$\$ 542,000$

7. Obligations and Cost Schedule:

\begin{tabular}{c} 
Fiscal Year \\
\hline 1962 \\
1963 \\
1964 \\
1964
\end{tabular}

\begin{tabular}{|c|c|}
\hline \multirow[t]{3}{*}{$\underline{\varepsilon}$} & $\$ \frac{\text { Obligations }}{93.000}$ \\
\hline & $\begin{array}{r}93,000 \\
512,000\end{array}$ \\
\hline & $\begin{array}{r}542,000 \\
-0- \\
\end{array}$ \\
\hline Total & $\$ 1,147,000$ \\
\hline
\end{tabular}

$\begin{array}{r}\text { Cost } 8 \\ 43,000 \\ 363,000 \\ 541,000 \\ 200,000 \\ \hline 1,147,000\end{array}$

8. Brief Physical Description of Project:

This is a recurring annual request for funds to cover those miscellaneous sub-projects of varying magnitude arising from the requirements of the program and in the conversion and modification of plant items to improve efficiency of operations. CANEL Facilities were transferred from the Department of the Alr Force to the A.E.C. effective October 1, 1961, $\$ 361,000$ of the requested funds are required to bring these facilities up to A.E.C. Health and Safety standards.

9. Justification of Need:

The need for the types of items 1 isted below by fiscal year is indicated by normal wear and tear, as well as experience and knowledge of pending requirements, to provide a basis for the budget request. The descriptions of many Items are self-explanatory in providing the best justiflcation, Also see CNLM 3869 dated December 1 , 1961: 


\section{Justification of Need (Continued)}

To be completed, committed or authorized FY 1962 - Project No. 443-62-k

\section{Repair of washout}

Replacement of 4 wood electrical poles

$\$ 9,000$

19,000

Repair of Heating and Vent. system (B1dg. \#450)

15,000

Aluminum jacketing outdoor pipelines - approximately 15,000 linear feet

63,000

Total FY 62

\section{To be completed, committed or authorized FY 1963}

Riprap river bottom and river dock No. 380, 500 tons

Storage racks Shop Lab No. 150 S.S. Vault, approximately 100 1inear feet

Shop Lab 150 Vault floor replacement, approximately 5,200 Sq. Ft.

8,000

Misc. drainage and paving modifications and additions

Installation of heating colls in zones 2 and 4, Bldg. No. 130

21, 000

5,000

Process water extension to Machine Shop, B1dg. No. 10

70,000

Rehabilitation to gas distribution systems

Replace wood electrical poles with steel poles, two poles at $\$ 5,000$ each

17,000

Safety and Fire protection subprojects:

Pump and turbine Lab No's. 330 and 340 bridge erane service ladders

10,000

Sprinklers and roof hydrants, Machine Shop No. 10

Fire detectors for buildings No. 107, No. 130 Vault, No. 260 , No. 270 , No. 280 and No. 425

Close water supply loop from Fuel Tank Farm to the Water Main near the Power House

Install pipel ine from quarry to Fire Water pumps in Building No. 105

Sprinklers, roof hydrants, hose boxes and yard hydrant Service Building No. 110

Sprinklers, roof hydrants and hose boxes, Gen. Lab No. 140

Sprinklers and roof hydrant Shop Lab No. 150

Sprinklers and yard hydrant for Propane Farm No. 153

Fire protection at transformers, H.E. Lab No. 290

Exit and directional signals misc. CANEL buildings

Roof hydrants and hose boxes, Power House No. 310

Roof hydrants and hose boxes, Pump and Turbine Lab No. 330

Sprinklers, roof hydrants and roof access ladders, Adm. Bldg. No. 130

Fuel Farm Foam System

Yard hydrants - Rad. Lab No, 270 and Incinerator No. 155

Fire Well extensions through roof and fire doors, Liquid Metal area, Shop Lab

No. 150 


\section{Justification of Need (Continued):}

Safety and Fire protection subprojects (Continued):

New exit from basement non-hazardous Pump and Turbine Lab No. 330

Isolate Paint Spray booth - Service Bldg. No. 110

Amounts

1,000

Waste baling machine - Hot Lab No. 450

Engineering and Design services for Safety and Fire Protection System subprojects

\section{Total FY 1963}

\section{The Following Work is Contemplated for FY 1964}

Install Flow Control System

Ref. Absorber Closed Cooling System - Corrosion Control

Corrosion Contro1 System (Condenser of Centravac Ref. Unit)

Ceiling High Partitions Around Heat Treat and Plating, Including H\&V Changes

Ceiling High Partitions Col. G Line and Around Truck Well

Instal1 Reheat Coil for AC-1 \& AC-2 Fuel Element Lab with Controls, Duct Work,etc.

Install 125' Trolley Crane (2-2000作 Holsts)

Pavement for Helium Trailers

Install $480 \mathrm{~V}$ Feeder

Modify Stokes Press

Electric Bus for Crane

New Domestic Well Connected to System

Roof Repair

Process Water System - Corrosion Contro1

Domestic Wel1 Water System - Corrosion Control

Arrange Power House Fue1 Oil Pumps - Auto Operations

Steam Reciprocating Pumps (to deliver fuel oil direct from Storage Tank to oil

burners or bollers)

O11 Storage Shed $16^{\prime} \times 24^{\prime}$

Additional Lighting in Storage Area to Convert to Shop Area

Extend Compressed Air to New Shop Area

Enlarge Office, Locker Room Trades Cribs

Office and Locker Room Expansion

Condenser for Air Compressor

Cover Duct Work Insulation with Canvas

Replace (5) Wood Electrical Poles with Steel Poles

Total General Plant Projects, 1964

$\$ 2,000$

2,500

2,500

20,000

37,000

12,000

12,600

1,400

4,000

1,500

1,500

125,000

30,000

35,000

25,000

13,000

6,000

7,000

2,000

2,000

20,000

15,000

30,000

3,000

25,000

$\$ 435,000$

Contingency (15\%)

65,000

A \& E Services

Total FY 1964 
10. Details of Cost Estimates

Part experience and preliminary studies are the basis for the itemization shown above.

11. Major Contractors and Intended Type of Contract

$A / E$ where required - not selected $A / E$ contracts - Lump sum construction contractors - not selected construction contracts - Lump sum.

12. Incorporation of Fallout Shelters in Future Federal Buildings

The nature of this project does not lend itself to inclusion of a fallout shelter.

$\therefore . . .:$

$\vdots \ldots:::$

…:

$\because:$

$\because \because:$

$\because \because \cdots$.

$\vdots \ldots .$.

$\therefore \therefore$

$\vdots . .,: \vdots$

$\therefore \ldots$ : 
SCHEDULE 44

Construction Project Data Sheet

Mew York

Reactor Development

Operations Office

Sub-Program

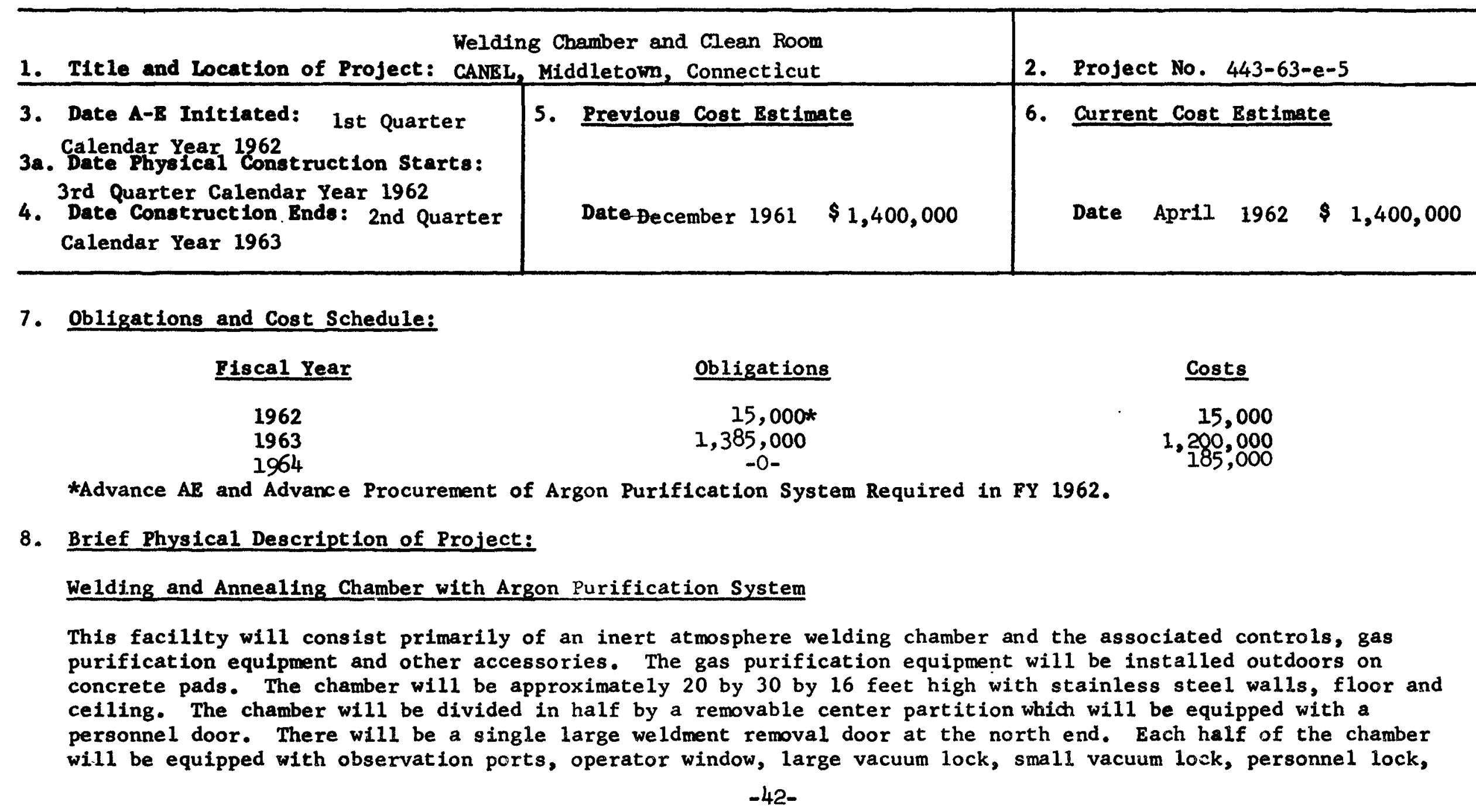

T...:

: :

$\therefore$ (n....

$\because \because$

$\because \because$

$\because \cdots$

(.....

$\therefore$

:....: concrete pads. The chamber will be approximately 20 by 30 by 16 feet high with stainless steel walls, floor and (a)

$-42-$ 


\section{Brief Physical Description of Project: (Cont'd)}

personnel escape door and pass-throughs as required. The chamber and all access doors, hatches, locks, etc. will be mass spectrometer leak tight. The design will be such that all welds, mechanical joints and other potential sources of leakage can be readily accessible. An argor purification system will be installed to continuously circulate and purify the chamber argon with reserve capacity to reclaim purge axgon currently being lost from existing shop processes. The system will incorporate a catalytic furnace, molecular sieves, fractional distillation columns and necessary accessories.

\section{Clean Room}

The clean room will be located in the Machine Shop and shall be constructed with the objective of minimizing the infiltration of dust particles. This will be accomplished by (1) maintaining an air pressure of 0.2 to 0.5 inch $\mathrm{H}_{2} \mathrm{O}$ within the room, (2) providing filtered air inlets as near the use points as possible, (3) providing wall construction of non-oxidizing materials such as porcelain or plastic coated panels, (4) providing ascessibility to all service equipment from outside the room, (5) eliminating all protruding horizontal surfaces capable of collecting dust particles, and (6) controlling personnel access to the room to an absolute minimum, and making mandatory the wearing of dust-free garments by working personnel. The air handling eystem will provide an environmental control of relative humidity, less than 50 percent and of tempersture, $72 \mathrm{~F} \pm 2 \mathrm{~F}$ and wall provide for an air balance within the enclosures to insure flow of air from clean areas to those in which some degree of contamination can be tolerated. Room construction will be modular in order to allow flexibility for future modifications of room configuration. Construction w11. include such features as rounded "cornerless construction" techniques, smooth vinyl floors with minimum joints, shadowless light fixture glass permitting approximately 100 foot candles of fluorescent illumination at working level, emerging exis, an outside vacuum cleaner system and a separate area for clothing storage (Change Room). 


\section{Justification of Need:}

\section{Welding and Annealing Chamber with Argon Purification System}

Welding and annealing of columbium must be performed in an inert atmosphere wherein impurity content is maintained at an extremely low level, in the range of $2 \mathrm{ppm}$ oxygen, $2 \mathrm{ppm}$ water and correspondingly low for all other impurities. Existing welding boxes are too small to handle the major columbium weldments of the proposed reactor power plant design.

\section{Clean Room}

$\ldots .$.

$\ldots:::$

$\ldots$

$\ldots$

$\because \because$

$\because$

$\because \because$.

$\cdots$

$\therefore$

...: :

$\ldots$

\section{Details of Cost Estimate:}

\section{Welding and Annealing Chamber with Argon Purification System}

A. A/E at 9 percent of construction costs

60,000

B. Land and Land Rights :an:

:::.: :

(1.....

:.....

(n....

$\because \because$

$\because \because$

$\because \ldots$

:

$\therefore$

...."

$\vdots . . .$.

$\because \cdots:$ 
Modifications and Additions 1. Title and Location of Project: CANEL, Middletown, Connecticut 2. Froject No. 443-63-e-5

\section{Details of Cost Estimate: (Cont'd)}

C. Construction Costs

Welding Chamber complete with Pass Throughs, air locks, doors, partitions, parts, etc.

$$
\begin{array}{r}
103,000 \\
25,000 \\
10,000 \\
25,000 \\
13,000 \\
5,000 \\
12,000 \\
1,500 \\
5,000 \\
3,000 \\
5,000 \\
2,500 \\
50,000 \\
450,000 \\
\hline
\end{array}
$$

\section{Foundation}

Stee 1work

Electrical

Vacuum System

Plumbing

Chamber Temperature Control System

Argon High Pressure Storage

Argon High Pressure Compressor

Argon Liquefier and Piping

Argon Low tressure Storage

Argon Vacuum Scavenge Pump

Instruments and Controls

Purification System

Total Constructic- Costs

\section{Equipment}

Gas-tight sults with brearing appaxatus Equipment and Furnishings

Total Equipreat Cost:

Total cost - rustorish and Equipment 


\section{Details of Cost Estimate: (Cont'd)}

Contingency at 15 percent of Other Costs

SUB-TOTAL - Welding and Annealing Chamber with Argon Purification System

\section{Clean Room}

A. $A / E$ at 7 percent of Construction Cost

30,000

B. Land and Land Rights

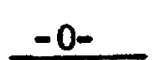

C. Construction Costs

\section{Partitions and Doors}

Ceiling Panels

Floor and coving

Pass Through windows, interlocked air-locks

Structural Steel, Clean Room and Mechanical Equipment Shelter

High Velocity Air Shower

Insulation, Painting, Rigging, Sheet Metal, Instrumentation, etc.

Electrical lights, $440 \mathrm{~V}$ and $115 \mathrm{~V}$ Power Supply

Environmental Control System

Plumbing Services

Vacuum Cleaning System

80,000

20,000

10,000

10,000

30,000

5,000

15,000

35,000

45,000

17,000

10,000

Total Construction Cost $\therefore \ldots$

30,000

- n....

$\vdots \ldots$

(a....

$\because \cdots$

$\because \because$

$\therefore$

$\ldots \ldots$

$\therefore \therefore$

:...:

$\therefore$ (a.: 
10. Details of Cost Estimate: (Cont'd)

\section{Equipment}

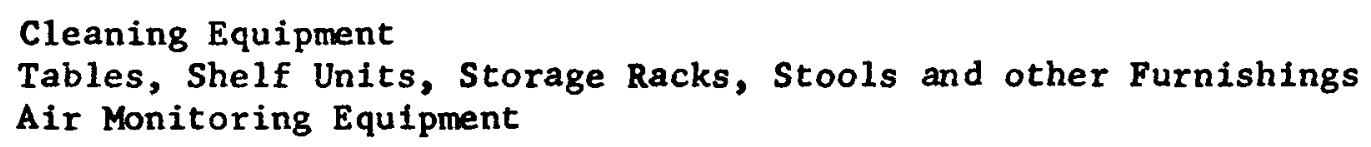


U.S. ATOMIC ENERGY COMMISSION

$$
\text { Schedule } 83
$$

Notor Vehicle and Aircraft Statement for F1scal Year 1964

New York Operations Office

Pratt \& Whitney Aircraft Division

CANEL, Middletown, Connecticut

\section{Description}

\section{To be Purchased}

Factory

No.

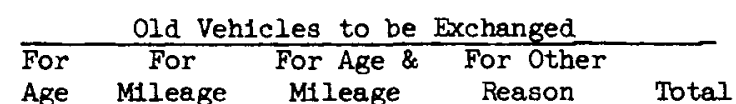

$\begin{array}{lll}\text { For } & \text { For Age \& } & \text { For Other } \\ \text { Reason }\end{array}$ Total \begin{tabular}{cl}
$\begin{array}{c}\text { Total } \\
\text { Estimated }\end{array}$ & Net \\
Allowance & Cost \\
\hline
\end{tabular}
$\mathrm{X}$ Equipment

Construction

\section{Motor Vehicles}

a. Passenger Vehicles Sub-total

b. Trucks Sub-total

Trailers

Aircraft

Total Motor Vehicles

and Aircraft

$\$ 50,000$

\section{Justification}

Although presently operating with 35 vehicles, demands have been increasing for more use. The SNAP-50 program will increase manpower and activity, and past experlence has shown that the number of vehicles in this request is the minimum necessary to provide the use and transportation required for the anticipated operations. Since all vehicles are presentiy provided from the GSA Motor Pool it is expected the additional trucks and cars will come from the same source.

Trucks

1 ton and under 26

$1 \frac{1}{2}$ ton thru $2 \frac{1}{2}$ ton 4

3 ton and over

**Special Purpose

26
4
3
$\frac{1}{34}$

* Include (I) automobile and (1) station wagon assigned to AEC-HAO

* Snow removal equipment as approved in letter March 8, 1962 by Charles Jenkins, Contract Administrator

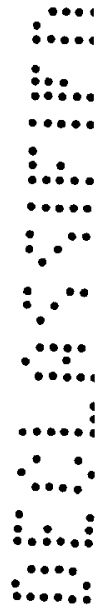

Cost of Hire $\quad$ Cost

ireraft 
New York

Operations Office

Field office
Analysis of Operating costs Incurred by Operating

Contractor
P\&W Aircraft

CANEL

Contractor
A. Costs to be Financed:

1. Costs by Program

Raw Materials

Special Nuclear Materials

\section{Weapons}

Reactor Development

Physical Research

Blology \& Medicine

Training, Education, \& Information

Isotope Development

Civilian Application of Nuclear Explosive

Community

Program Direction \& Administration

Cost of Work for Others

Adjustment to Prior Yeas costs

Total Operating Cosis

\section{Revenues}

Total Net Operating Costs

3. Costs Transferred to Other's

4. Costs Transferred from Giners

5. Total Operating Costs under Contraci

6. Increase or Decrease in Inventories

7. Total costs to be Financed

B. Outstanding Commitments at End of Fiscal Year for Operations :

I. Purchase Orders for Supplies, Materials, etc.

2. Service Contracts including Utilities

3. Subcontracts

4. Other

Total
FY1962

$\$$

$16,849, \infty 00$

$27,000,000$

$37,909,000$

\begin{tabular}{lll}
\hline $16,849,000 \cdot$ & $37,909,000$. \\
\hline $16,849,000$. & $27,000,000 \cdot$ & $37,909,000 \cdot$ \\
\hline $27,000,000$. & $37,909,000$
\end{tabular}

\begin{tabular}{lll}
$(256,930)$ & $(85,300)$ & $(111,900)$ \\
\hline $16,592,070$. & $26,914,700$ & $37,797,100$. \\
$(1,534,570)$. & $(1,957,000)$. & $(1,700,000)$. \\
$\$ 15,057,900$. & $\$ 24,957,700$ & $\$ 36,097,100$. \\
\hline
\end{tabular}

$\therefore . .$.

:::..

$\because$

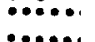

$\because \because$

$\because \because$

$\because \ldots$

$\ldots$

$\therefore \therefore$

i.,

$\because \ldots$

$\$ 2,007,000 . \quad \$ 2,218,000 . \quad \$ 2,218,000$ 
SCHEDULE 91 - (cont'd)

Analysis of Operating costs

Incurred by Operating

Contractor
New York

Operations Office
Field office

P\&W Aircraft

CANEL

Contractor

FY1962

$\$$

$6,477,700$

FY1963

FY1964

C. Operating Costs by Type of Expense:

1. Salaries \& Wages

2. Employee Fringe Benefits

3. Travel

4. Communications

5. Rental of Land \& Buildings

6. Power

7. Fuel

8. Materials \& Supplies other than Fuel

9. Subcontracts

10. Fees or Home Office Overhead

11. Other

12. Total Operating Costs under Contract

D. Operating Costs by Category:

1. Administrative Expense

2. Maintenance of Plant

3. Other Operating Expense

4. Total Operating Costs under Contract
$\$$

$8,678,000$

\begin{tabular}{rrr}
$3,032,000$ & $7,557,100$ & $6,707,900$ \\
215,000 & 491,900 & 518,100 \\
$6,829,300$ & $9,901,000$ & $15,792,300$ \\
295,000 & 372,000 & $2,165,000$ \\
$\$ 16,849,000$ & $\$ 27,000,000$ & $\$ 37,909,000$ \\
\hline
\end{tabular}

$\$ 16,849,000$

$\$$

$12,725,700$

$\ldots . .$. :

$\because \because:$

$\therefore .:$

$\because \cdots$

(

$\therefore \therefore$

...: :

(..:

$\ldots$ : 